\title{
Tectonic geomorphology of Australia
}

\author{
MARK C. QUIGLEY ${ }^{1 *}$, DAN CLARK ${ }^{2} \&$ MIKE SANDIFORD ${ }^{3}$ \\ ${ }^{1}$ Department of Geological Sciences, University of Canterbury, Christchurch 8014, \\ New Zealand \\ ${ }^{2}$ Geoscience Australia, GPO Box 378, Canberra, ACT, 2601, Australia \\ ${ }^{3}$ School of Earth Sciences, University of Melbourne, Melbourne, Victoria 3010, Australia \\ *Corresponding author (e-mail: mark.quigley@canterbury.ac.nz)
}

\begin{abstract}
The Australian continent is actively deforming in response to far-field stresses generated by plate boundary interactions and buoyancy forces associated with mantle dynamics. On the largest scale (several $10^{3} \mathrm{~km}$ ), the submergence of the northern continental shelf is driven by dynamic topography caused by mantle downwelling along the Indo-Pacific subduction system and accentuated by a regionally elevated geoid. The emergence of the southern shelf is attributed to the progressive movement of Australia away from a dynamic topography low. On the intermediate scale (several $10^{2} \mathrm{~km}$ ), low-amplitude $(c .100-200 \mathrm{~m}$ ) long-wavelength (c. $100-300 \mathrm{~km}$ ) topographic undulations are driven by (1) anomalous, smaller-scale upper mantle convection, and/or (2) lithospheric-scale buckling associated with plate boundary tectonic forcing. On the smallest scale $\left(10^{1} \mathrm{~km}\right)$, fault-related deformation driven by partitioning of far-field stresses has modified surface topography at rates of up to $c .170 \mathrm{~m} \mathrm{Ma}^{-1}$, generated more than $30-50 \%$ of the contemporary topographic relief between some of Australia's highlands and adjacent piedmonts, and exerted a first-order control on long-term $\left(10^{4}-10^{6}\right.$ a) bedrock erosion. Although Australia is often regarded as tectonically and geomorphologically quiescent, Neogene to Recent tectonically induced landscape evolution has occurred across the continent, with geomorphological expressions ranging from mild to dramatic.
\end{abstract}

Australia is one of the lowest, flattest, most arid, and most slowly eroding continents on Earth. The average elevation of the continent is only $c .330 \mathrm{~m}$ above sea level (asl), maximum local topographic relief is everywhere $<1500 \mathrm{~m}$ (defined by elevation ranges with $100 \mathrm{~km}$ radii) and two-thirds of the continent is semi-arid to arid. With the exception of localized upland areas in the Flinders and Mt Lofty Ranges and the Eastern Highlands, bedrock erosion rates are typically $\leq 1-10 \mathrm{~m} \mathrm{Ma}^{-1}$ (Wellman \& McDougall 1974; Bishop 1984, 1985; Young \& MacDougall 1993; Bierman \& Caffee 2002; Belton et al. 2004; Chappell 2006). Despite this apparent geomorphological longevity, Australia has had a dynamic Neogene to Recent tectonic history. Australia has migrated more than $3000 \mathrm{~km}$ to the NNE at a rate of $6-7 \mathrm{~cm} \mathrm{a}^{-1}$ over the past $45 \mathrm{Ma}$ as part of the Indo-Australian Plate (Fig. 1) (DeMets et al. 1990, 1994; Bock et al. 2003), making it the fastest moving continent since the Eocene (Sandiford 2007). Australia experiences a relatively high level of seismicity for a supposedly 'stable' intraplate continental region (Johnston et al. 1994; Johnston 1996) and has a rich record of Neogene and Quaternary faulting (e.g. Andrews 1910; Fenner 1930, 1931; Miles 1952; Beavis 1960; Hills 1961; Sandiford 2003b; Quigley et al. 2006; Hillis et al. 2008). Thus, although large parts of the Australian landscape are likely to be ancient (e.g. Twidale 1994, 2000) features reflecting recent landscape rejuvenation in response to Neogene to Recent plate motion and associated intraplate deformation are widespread (Sandiford 2003a, $b$; Sandiford et al. 2009). Quantitative landscape analysis indicates that even some apparently ancient landscapes have undergone kilometre-scale burial and denudation through the Phanerozoic in the arid continental interior (Belton et al. 2004).

In this paper, we reveal how intraplate tectonism and mantle processes have contributed to the Neogene to Recent geomorphological evolution of the Australian continent. We summarize geological evidence for distinct modes of deformation and speculate on how each deformation mode has influenced the spatial and temporal evolution of Australia's coastlines, uplands, interior basins and fluvial systems. Although pre-Pliocene fault-related tectonic activity in onshore Australia was widespread in the Tertiary (e.g. Raiber \& Webb 2008) we restrict most of our discussion here to faulting during the Pliocene to Recent interval, as these faults are typically considered 'active' in the Australian context (Sandiford 2003b). We contend that Neogene to Recent tectonism, particularly in the last c. $5 \mathrm{Ma}$, and mantle processes have exerted an 


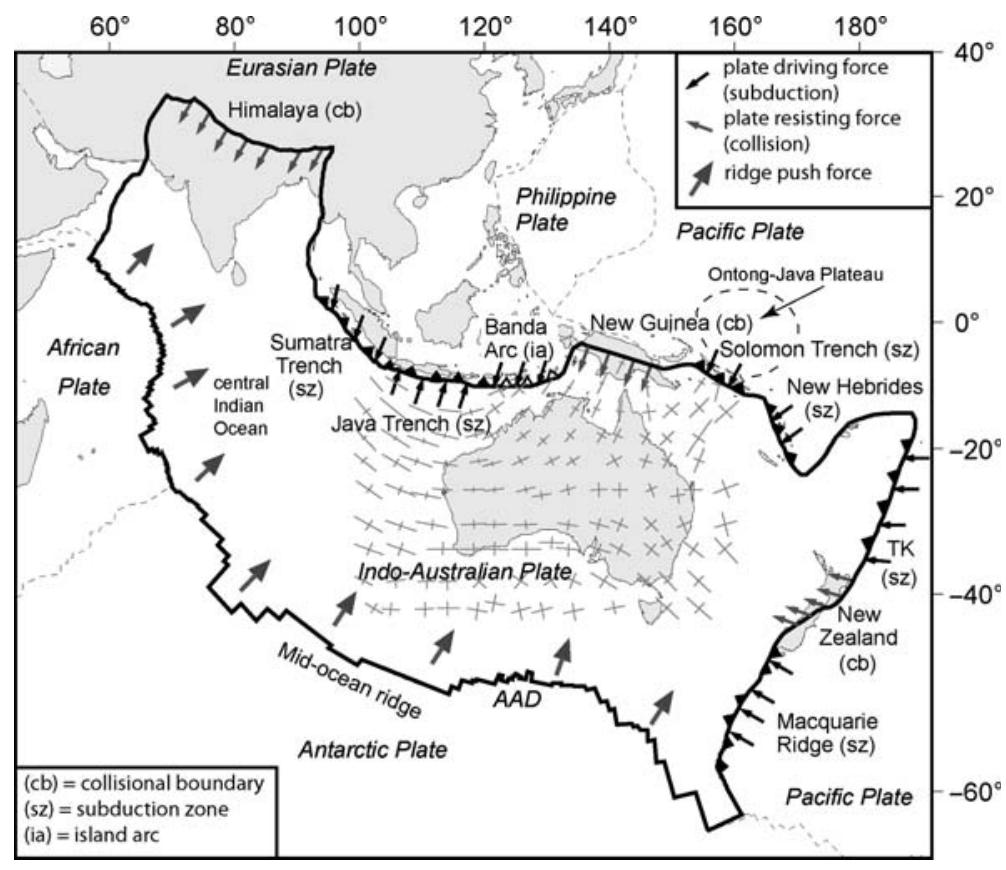

Fig. 1. Indo-Australian Plate with plate boundary forces and orientation of modelled maximum and minimum horizontal stresses used in the finite-element stress modelling of Reynolds et al. (2003). Much of the southern part of the continent has an east-west-oriented maximum horizontal compressive stress oriented at a high angle to the NNE-oriented plate velocity vector. Filled triangles along plate boundary indicate the direction of subduction; open triangles delineate the Banda Arc. TK, Tonga-Kermadec Trench; AAD, Australian-Antarctic discordance (from Reynolds et al. 2003; Hillis et al. 2008).

influence on the geomorphological evolution of the Australian landscape, and must be considered when interpreting contemporary Australian landforms.

\section{The Australian intraplate stress field: characteristics, age and origin}

Indo-Australian Plate (IAP) motion is driven principally by the 'pull force' associated with subduction zones in the Indonesia region and is resisted by continent-continent collision in the Himalayan, New Zealand and New Guinea orogens (Fig. 1; Coblentz et al. 1995, 1998; Sandiford et al. 2004). The Australian in situ stress field, as inferred from earthquake focal mechanism solutions, borehole breakouts and fracture arrays (Hillis et al. 2008), is unusual for a plate interior in that it is characterized by maximum horizontal compressive stress azimuths $\left(\sigma_{\mathrm{Hmax}}\right)$ oriented at a high angle to the NNE-oriented plate velocity vector. $\sigma_{\mathrm{Hmax}}$ varies from roughly east-west in western and southcentral Australia, to NE-SW in northern, central and central-east Australia, to NNE-SSW in NE Australia, and to NW-SE in SE Australia (Fig. 1).
The modern in situ stress field has been extrapolated back to the terminal Miocene-early Pliocene (10-6 Ma) by comparing $\sigma_{\mathrm{Hmax}}$ trends with palaeo-stress orientations inferred from kinematic investigations of Plio-Quaternary faults (Fig. 2a; Sandiford 2003b; Celerier et al. 2005; Quigley et al. 2006; Green 2007) and structural-stratigraphic relationships in Neogene strata (Fig. 2b, c; Dickinson et al. 2001, 2002; Sandiford 2003b). For instance, sedimentary basins in SE Australia (e.g. the Gippsland and Otway Basins) underwent significant inversion at c. 8-6 Ma (Dickinson et al. 2002; Sandiford 2003b; Sandiford et al. 2004). Reverse faults preserved in the offshore record parallel Plio-Quaternary structures in onshore basins (Sandiford 2003b; Sandiford et al. 2004), and up to $1 \mathrm{~km}$ of stratigraphic section has been locally removed on reverse fault-bounded topographic highs, suggesting that a significant episode of tectonic uplift and accompanying erosion occurred in this time interval (Dickinson et al. 2001; Sandiford 2003b). Sandiford et al. (2004) attributed the NW-SEoriented $\sigma_{\mathrm{Hmax}}$ in SE Australia to increased intraplate stress levels associated with the increased IAP-Pacific Plate coupling and uplift of the 

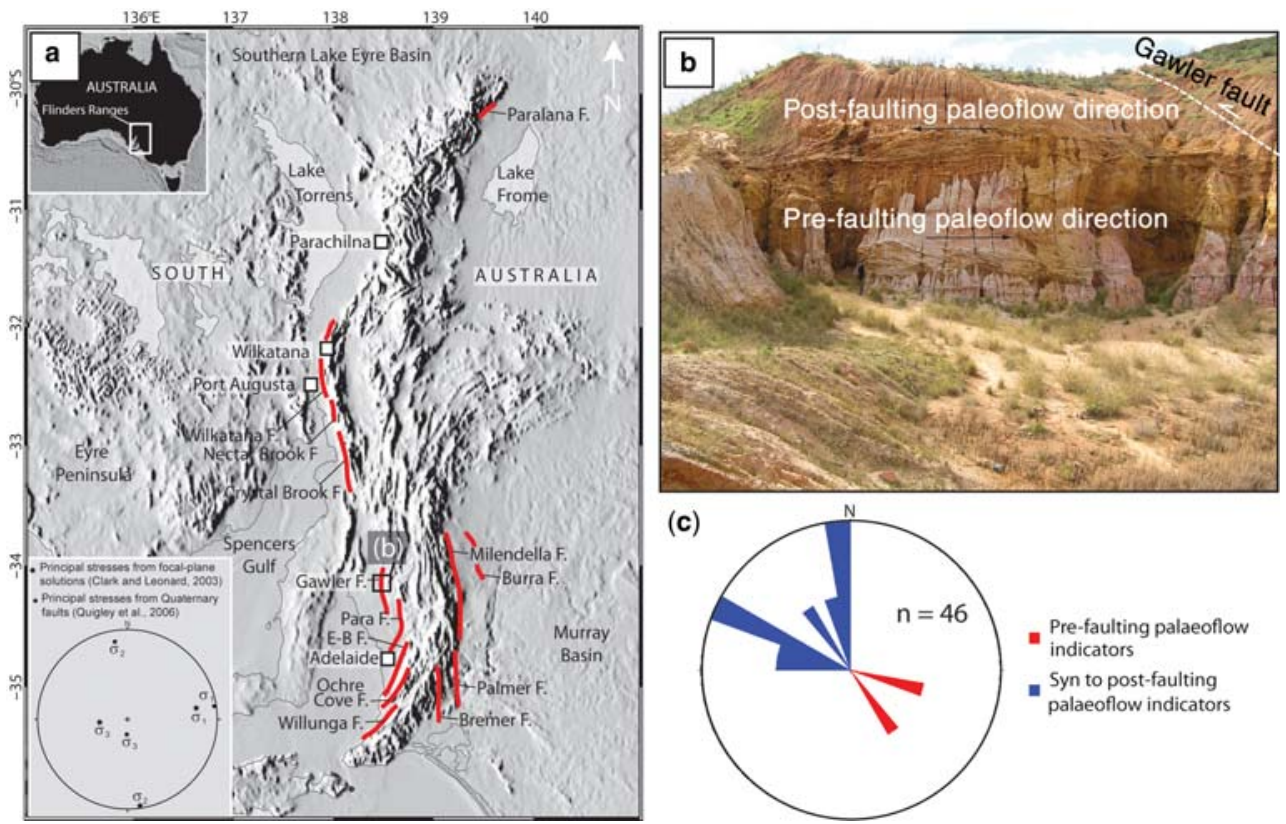

Fig. 2. (a) Flinders Ranges DEM with locations of Quaternary faults. E-B F., Eden-Burnside Fault. Further details have been given by Sandiford (2003b). Lower inset shows consistency between principal stresses estimated from earthquake focal mechanisms and those determined from geological studies of Quaternary faults (specifically, the Wilkatana, Burra and Mundi Mundi Faults) (from Quigley et al. 2006). (b) Cross-sectional view of alluvial sediments in the footwall of the Gawler Fault looking NE, showing a Mid- to Late Miocene reversal in drainage flow direction from towards the fault (SE) to parallel to the fault (north to NE), postulated to be the result of fault activity (from Green 2007). (c) Rose diagram showing palaeoflow directions obtained from cross-bed orientations and clast imbrication in the section shown in (b). The change in palaeoflow should be noted, from SE-directed prior to Gawler Fault initiation to NE-directed during or after fault growth, implying drainage reversal as a result of faulting (from Green 2007).

Southern Alps in New Zealand at c. 5-10 Ma (Wellman 1979; Batt \& Braun 1999).

In central southern Australia, stress conditions consistent with the modern stress field may have been established somewhat earlier. Mid- to late Miocene alluvial sequences west of the Mt Lofty Ranges reveal drainage direction shifts from eastward-directed palaeo-flow towards impending uplifts to northward-directed palaeo-flow adjacent to north-south-oriented reverse fault scarps, implying that tectonic uplift associated with roughly east-west compression caused drainage reorganization by the terminal Miocene (Fig. 2b, c; Green 2007). At Sellicks Beach, subvertical Cambrian sedimentary rocks are unconformably overlain by steeply west-dipping Oligocene sedimentary rocks that are, in turn, overlain by moderately westdipping Oligo-Miocene sedimentary rocks and, finally, gently west-dipping Pleistocene gravels (Lemon \& McGowran 1989). This series of progressive unconformities, ranging in age from possibly Late Eocene or Early Oligocene through the Miocene, Pliocene and Pleistocene suggests that the processes governing tectonic tilting of these sequences have been active since at least the Oligocene (Lemon \& McGowran 1989). The trace of a locally exposed ESE-dipping reverse fault lies west of these outcrops, implying that movement on this fault may have been responsible for the observed structural geometry. Computer modelling of the structural relationships is consistent with formation as a result of fault-propagated folding (Lemon \& McGowran 1989) in response to roughly east-west shortening, although the fault geometry is not well constrained. The kinematic consistency between Oligocene(?) deformation and more recent tectonism implies that the same tectonic stresses may have driven these deformation regimes. Deformation is likely to have occurred in discrete pulses as opposed to being continuous (Dyksterhuis \& Müller 2008). On the basis of numerical stress modelling, Dyksterhuis \& Müller (2008) proposed that periods of roughly east-west compressional tectonism may have affected the Flinders Ranges in the Eocene (beginning at c. $55 \mathrm{Ma}$ ) and from $c .12 \mathrm{Ma}$ to the present, separated by an early to mid-Miocene period of tectonic quiescence. 
In NW Australia, transpressional deformation and uplift of parts of the NW Shelf initiated in the interval 11-5.5 Ma, with distinct deformation pulses recognized at $c .8 \mathrm{Ma}$ and $c .3 \mathrm{Ma}$ (Packham 1996; Keep et al. 2000, 2002). Reverse faulting and growth of fault propagation anticlines in the Carnarvon Basin continue to the present, as indicated by the uplift of Pleistocene marine terraces (van de Graaff et al. 1976).

In summary, the bulk of structural-stratigraphic evidence suggests that the modern, intraplate stress field was firmly entrenched by the mid- to late Miocene (Dickinson et al. 2001; Sandiford et al. 2004; Hillis et al. 2008), with the possibility that deformation within a regime similar to the modern tectonic regime began as early as the Eocene or Oligocene in south-central Australia (Lemon \& McGowran 1989). Plate-scale finite-element modelling of the IAP intraplate stress field replicates $\sigma_{\text {Hmax }}$ trends by balancing plate driving forces (slabpull and ridge-push), plate resisting forces (compression associated with the Indo-Asian collisional front in the Himalayas, the New Guinea fold-andthrust belt, and the New Zealand Southern Alps) and tractions induced by mantle flow (Coblentz et al. 1995, 1998). Using inferences drawn from stress modelling studies, Sandiford et al. (2004) attributed the 10-6 Ma onset of active tectonism in SE Australia to the synchronous development of transpression along the IAP-Pacific Plate boundary segments of southern New Zealand, the Puyseguer Trench and the Macquarie Ridge (Walcott 1998; Massell et al. 2000). However, it is also worth noting that the onset of deformation in the central Indian Ocean at around this time has been attributed to increases in stress levels propagated from the Himalayan-Tibet system (Molnar et al. 1993; Martinod \& Molnar 1995). These results imply that a significant component of the intraplate stress field relates to forces exerted from orogenic belts up to several thousands of kilometres from the plate interior (Coblentz et al. 1995, 1998; Reynolds et al. 2003; Sandiford et al. 2004). Hence, the IAP appears to have responded with increasing intraplate compression to a complex evolving plate boundary scenario over the last $10 \mathrm{Ma}$, and the onset of faulting at specific intraplate locations probably reflects rising stress levels related to the combination of all plate boundary forcings (e.g. Dyksterhuis \& Müller 2008).

\section{The mantle, the geoid, and dynamic topography}

The mean shape of the Earth contains longwavelength (up to 0.5 of Earth's circumference), low-amplitude $(c .300 \mathrm{~m})$ deviations from a perfect mathematical ellipsoid that relate to variations in density distribution within the deep mantle. This varying gravitational equipotential surface is called the geoid and is best approximated by global mean sea level. Where a relative density deficiency exists the geoid (sea level) will dip below the mean ellipsoid, and where a relative density surplus exists the geoid (sea level) will rise above the mean ellipsoid.

The term dynamic topography refers to the deflection of the solid surface of the Earth resulting from buoyancy forces associated with thermal convection in the viscous mantle. The wavelength of dynamic topography relates to the depth and scale of convection. Whole-mantle convection is likely to produce undulations on a similar scale to geoid undulations (several thousand kilometres wavelength, $\pm 500 \mathrm{~m}$ amplitude; Kaban et al. 2005), whereas shallow convection in the upper sublithospheric mantle would result in undulations of the order of several hundred kilometres wavelength. Mantle upwelling will result in positive dynamic topography and downwelling in negative dynamic topography. Dynamic topography has been used elsewhere to explain large-scale subsidence patterns on continental platforms and in sedimentary basins (Mitrovica et al. 1989; Gurnis 1992; Stern et al. 1992; Russell \& Gurnis 1994; Pysklywec \& Mitrovica 1999; Wegmann et al. 2007). Modelling studies predict that dynamic topographic undulations may reach several kilometres in amplitude (Lithgow-Bertelloni \& Gurnis 1997).

For several reasons, the Australian continent is arguably the best natural laboratory on Earth for investigating the topographic and geomorphological effects of geoid variations and dynamic topography through the Neogene. On its voyage towards an active subduction realm and away from a mid-ocean ridge, Australia has traversed a region of the geoid with a present-day change in height from $-20 \mathrm{~m}$ in the Southern Ocean to $+80 \mathrm{~m}$ in Melanesia (Sandiford 2007). This voyage has resulted in the extensive preservation of palaeo-shorelines that provide a datum of long-wavelength changes in the position of the continent relative to palaeo-sea level. The Australian coastline is beyond the flexural response wavelength (c. 200-300 km) of active plate boundaries, and thus crustal deformation is not driven by plate flexure associated with subduction. Long- to intermediate-wavelength changes in surface topography and geomorphology can thus been interpreted within the context of geoid anomalies and dynamic topography (Sandiford 2007; Sandiford \& Egholm 2008; Sandiford et al. 2009), although offshore sedimentation may have contributed some component to the subsidence by enhancing crustal flexure (e.g. Pazzaglia \& Gardner 1994). 


\section{Long-wavelength $\left(10^{3} \mathrm{~km}\right)$ deformation}

\section{Characteristics}

The width of the continental shelf and the distribution of Cenozoic marine and nearshore sediments around the Australian margin are highly asymmetric (Fig. 3). The southern continental shelf has a characteristic width of $c .100 \mathrm{~km}$ and ranges from 20 to $200 \mathrm{~km}$ wide. Eocene to Quaternary marine deposits are preserved up to several hundred kilometres inland, and up to $250 \mathrm{~m}$ above current sea level (Sandiford 2007). The northern shelf is almost everywhere $>200 \mathrm{~km}$ wide and is locally as broad as $500 \mathrm{~km}$. Eocene to Quaternary marine deposits are almost entirely situated offshore up to $50 \mathrm{~m}$ below sea level (Veevers 2000), indicating that northern shelf subsidence has exceeded the progressive Neogene eustatic sea-level fall of c. 100-150 m (Sandiford 2007). The variations in

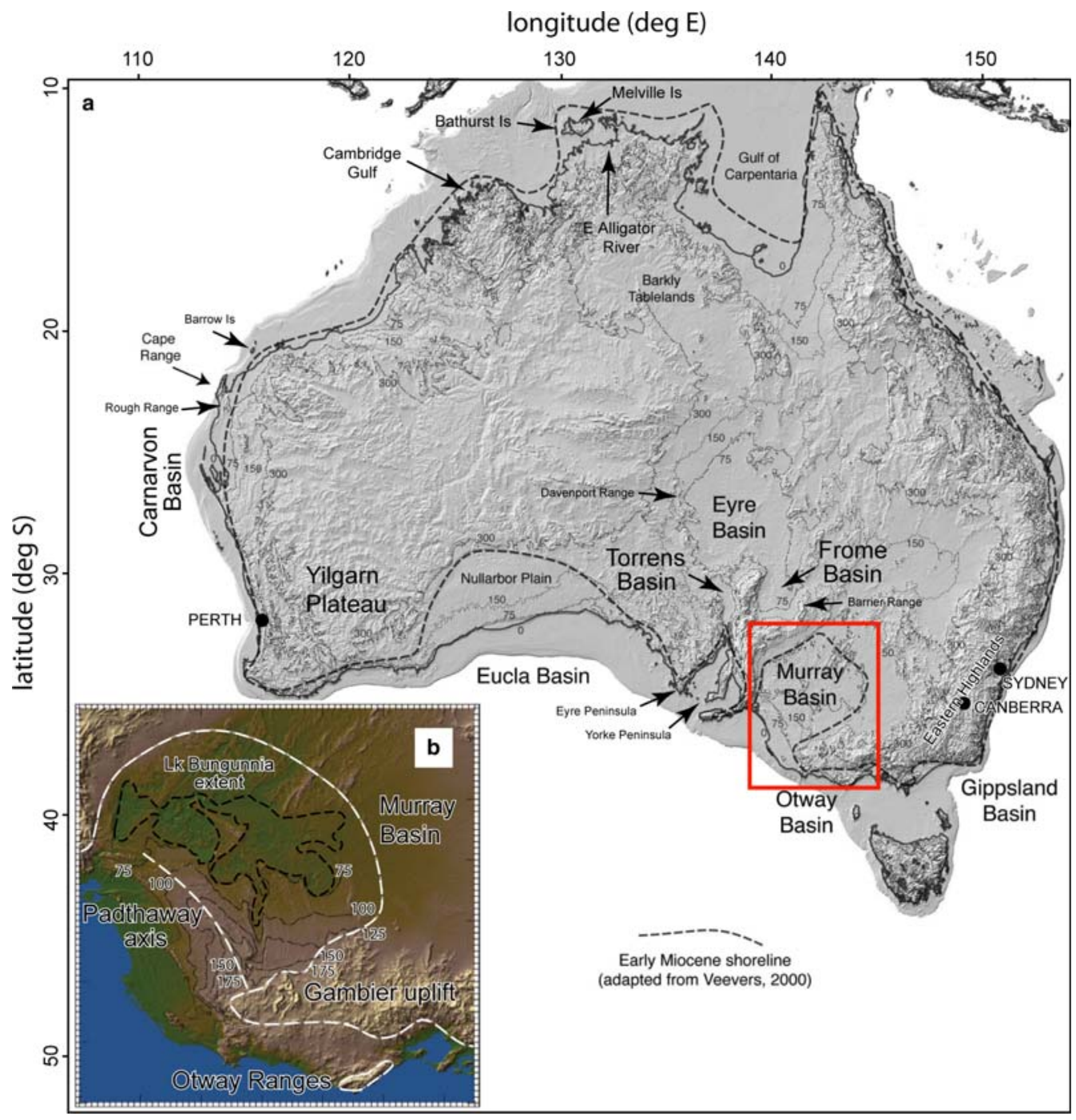

Fig. 3. (a) Shaded relief image of the Australian continent and its continental shelf (at elevations greater than $-250 \mathrm{~m}$ ) derived from Geoscience Australia's 9 arc second 'bathytopo' dataset. Contours are shown for 75, 150 and $300 \mathrm{~m}$. The thick dashed line shows the approximate position of Early Miocene shorelines (from Veevers 2000; Sandiford 2007). (b) Shaded relief image of the Murray Basin showing the Padthaway and Gambier uplifts, and the former extent of Lake Bungunnia. The $25 \mathrm{~m}$ topographic contours across the Padthaway axis are also marked (from Sandiford et al. 2009). 
shelf thickness and distribution of marine deposits between the northern and southern Australian continental shelves imply a differential vertical displacement between SW and north Australia of c. $300 \mathrm{~m}$ since the late Eocene. The asymmetric pattern of Eocene to Pliocene shorelines is similarly found in last interglacial shoreline elevations, which tend to be elevated along the southern margin by several metres relative to the northern margin (Murray-Wallace \& Belperio 1991; Belperio et al. 2002), implying that the forces driving this asymmetry continue to be active.
Long-wavelength variations in marine shoreline elevation are also evident across the southern part of the continent. Early Neogene shorelines decrease eastward from c. $250 \mathrm{~m}$ asl in the western Eucla Basin to $c .100 \mathrm{~m}$ asl in the eastern Eucla Basin over a distance of $c .1000 \mathrm{~km}$, implying as much as $c$. $150 \mathrm{~m}$ of post mid-Neogene $(<15 \mathrm{Ma})$, longwavelength differential vertical displacement (Figs $3 \& 4$ ). This implies an uplift of $c$. 100$150 \mathrm{~m}$ for the western Eucla Basin when corrected for Neogene eustatic sea levels. Pliocene marine sequences in the Eucla Basin are restricted to
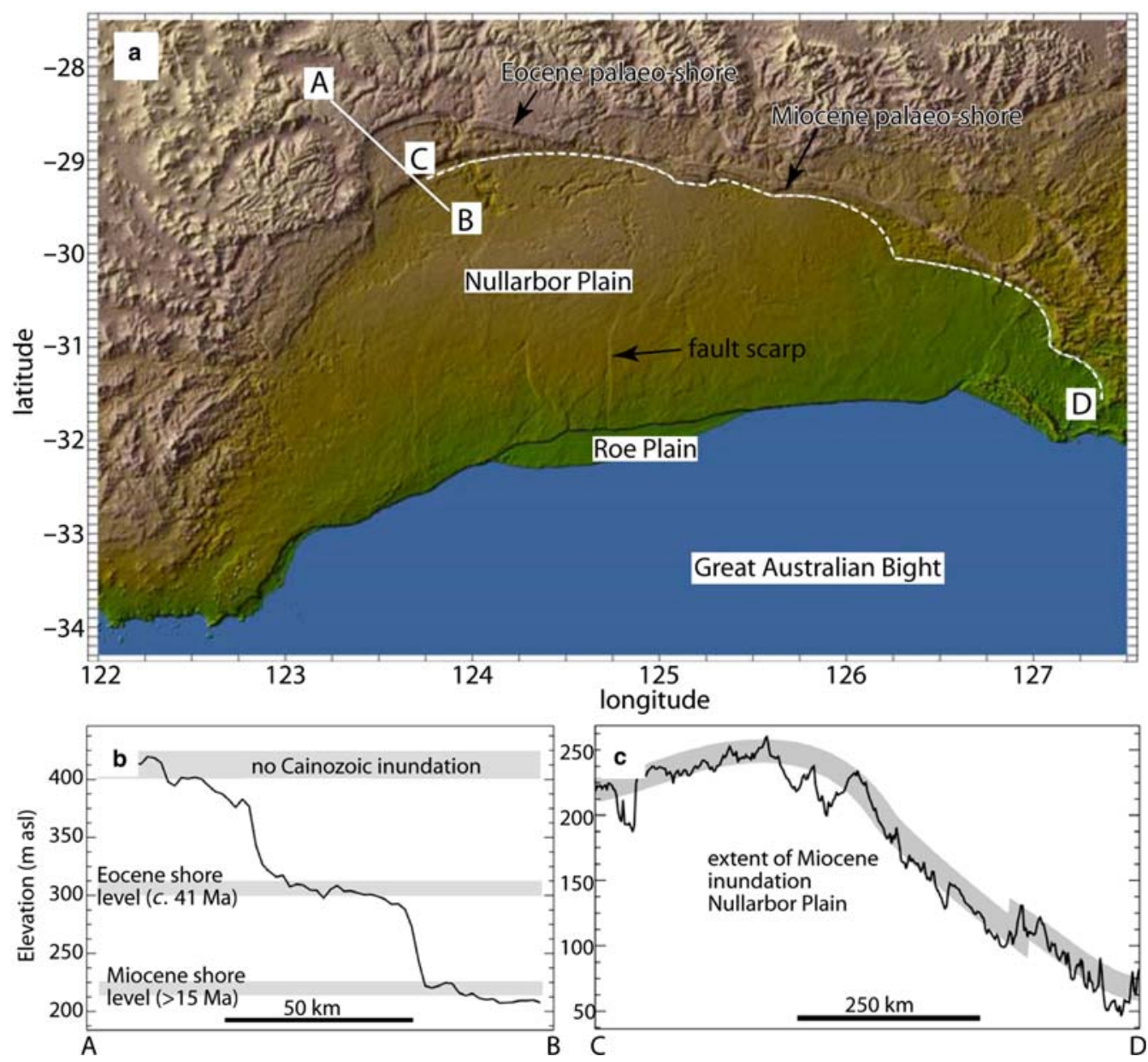

Fig. 4. (a) Shaded relief of the Nullarbor Plain showing various palaeo-shoreline features of Eocene to mid-Miocene age ( $>15 \mathrm{Ma})$ along its northern margin. The Roe Plain is a Pliocene surface. North-south-trending faults crossing the Nullarbor Plain have cumulative throws of up to $30 \mathrm{~m}$ (from Sandiford et al. 2009). (b) Section A-B normal to the palaeo-shorelines in the northwestern part of the Eucla Basin showing inundation levels. (c) Section C-D parallel to the northern margin of the Nullarbor Plain showing the interpreted limit of Miocene inundation. The lowest frequency component (indicated by the grey band), at wavelengths of order $103 \mathrm{~km}$, implies a deep mantle origin related to dynamic topography. 
elevations of $\leq 40 \mathrm{~m}$ asl and are nowhere present on the surface of the Nullarbor Plain, implying that post-Miocene sea levels never encroached onto land surfaces above $c .70 \mathrm{~m}$ asl. In the central Murray Basin, Miocene and Pliocene strand-lines are at equivalent elevations (c. $70 \mathrm{~m}$ asl), implying minimal Mio-Pliocene basin uplift. The consistency between Pliocene strandline elevations between these regions suggests that the western Eucla is uplifted by $c .180 \mathrm{~m}$ relative to the Murray Basin, and most of this uplift is constrained to the 15-5 Ma interval.

\section{Origin and rates}

The apparent sinking of the northern part of the Australian continent inferred from the absence of onshore Cenozoic shorelines and record of stratal onlap implies that the northern margin has subsided at higher rates than the long-term, Neogene eustatic sea-level fall of c. 100-150 m (Sandiford 2007). This subsidence reflects the progressive transport of the Australian continent towards a geoid high and dynamic topography low associated with the active subduction realm to the north. Separating the geoid from dynamic topography fields is challenging; however, if one assumes that the presentday geoid provides an adequate representation of the geoid in the past, then the northern margin of the continent has traversed a geoid gradient of c. 30-40 m over the last $15 \mathrm{Ma}$ (Sandiford 2007), consistent with an instantaneous rate of change in geoid height along the northern continental margin of $c .+2 \mathrm{~m} \mathrm{Ma}^{-1}$ (Sandiford \& Quigley 2009). The geoid effect accounts for c. 20-40\% of the c. $100-150 \mathrm{~m}$ of total subsidence, leaving a remaining signal of $c .60-110 \mathrm{~m}$ to be accounted for by the dynamic topographic effect associated with downward tilting of the continental shelf in the direction of plate motion plus any effects of subsidence caused by sediment loading.

The uplift of the SW part of the continent is thought to relate to the progressive northward movement of the continent away from a dynamic topography low (Sandiford 2007; Sandiford \& Quigley 2009). The dynamic topography low south of Australia is indicated by the anomalously low elevation of the mid-ocean ridge along the Australian-Antarctic discordance (AAD) (Fig. 1), attributed to the presence of a relict of a former slab residing above the mantle transition zone (Gurnis et al. 1998). Movement of the continent away from this anomalous mantle is responsible for a dynamic topographic uplift of up to $c .200 \mathrm{~m}$ in amplitude between 15 and $5 \mathrm{Ma}$, equivalent to a rate of c. $20 \mathrm{~m} \mathrm{Ma}^{-1}$ (Sandiford 2007; Sandiford et al. 2009). The instantaneous rate of change in geoid height along the southern continental margin varies between -0.2 and $+1 \mathrm{~m} \mathrm{Ma}^{-1}$, with the lowest rates in the $\mathrm{SW}$ part of the continent (Sandiford \& Quigley 2009).

The combined effect of northern shelf submergence and southwestern shelf emergence has resulted in a c. $300 \mathrm{~m}$ differential continental 'tilting' over the last $15 \mathrm{Ma}$ at a rate of $c .10-20 \mathrm{~m} \mathrm{Ma}^{-1}$ (Sandiford 2007). Although the rate of dynamic topographic forcing is several orders of magnitude lower than maximum eustatic sea-level changes, the finite amplitude of dynamic topography is larger than the eustatic variation, at least since the Neogene. In this respect, Australia's tectonic voyage across geoid undulations and changes in the dynamic topography may be as important as climate-driven sea-level fluctuations when considering the long-term geomorphological evolution of the continent.

\section{Geomorphological implications}

The influence of persistent downward displacement of the northern Australian land surface has resulted in low stream gradients $(<1 \mathrm{~m}$ per $10 \mathrm{~km})$ in major river systems draining to the north (e.g. Alligator River, NT, Fig. 3). Nearshore surface elevations are generally restricted to $<50 \mathrm{~m}$ within $30 \mathrm{~km}$ from the northern coastline. Offshore bathymetry between Australia and Papua New Guinea is almost entirely $<100 \mathrm{~m}$ deep and is punctuated by numerous large offshore islands (Melville, Bathurst; Fig. 3).

Upward displacement of the SSW part of Australia has also affected stream development. The formation of cave systems in the Nullarbor may relate in part to dynamic topographic uplift as ground water tables lowered to keep pace with regional base-level lowering (Webb \& James 2006). The formation of early Middle Eocene stranded inset valleys (palaeochannels) on the Yilgarn Plateau (Fig. 3) has been attributed to lowered geomorphological base level and increased stream gradients associated with slow surface uplift (de Broeckert \& Sandiford 2005). Longitudinal profiles of west-flowing streams, including the Avon River NE of Perth (Fig. 5), show convex-up 'disequilibrium' longitudinal profiles, implying that incision has been outpaced by relative base-level fall (Fig. 5). It is highly improbable that these profiles relate to escarpment formation, which took place in the Late Eocene (Beard 2003). Late Quaternary incision rates derived from cosmogenic ${ }^{10} \mathrm{Be}$ and ${ }^{26} \mathrm{Al}$ dating of bedrock surfaces at the base of the Avon River (c. $3.5 \mathrm{~m} \mathrm{Ma}^{-1}$ ) are slower than estimated dynamic topography uplift rates of $10-20 \mathrm{~m} \mathrm{Ma}^{-1}$ (see above), implying that the formation and maintenance of steepened stream longitudinal profiles may be attributed to upstream 

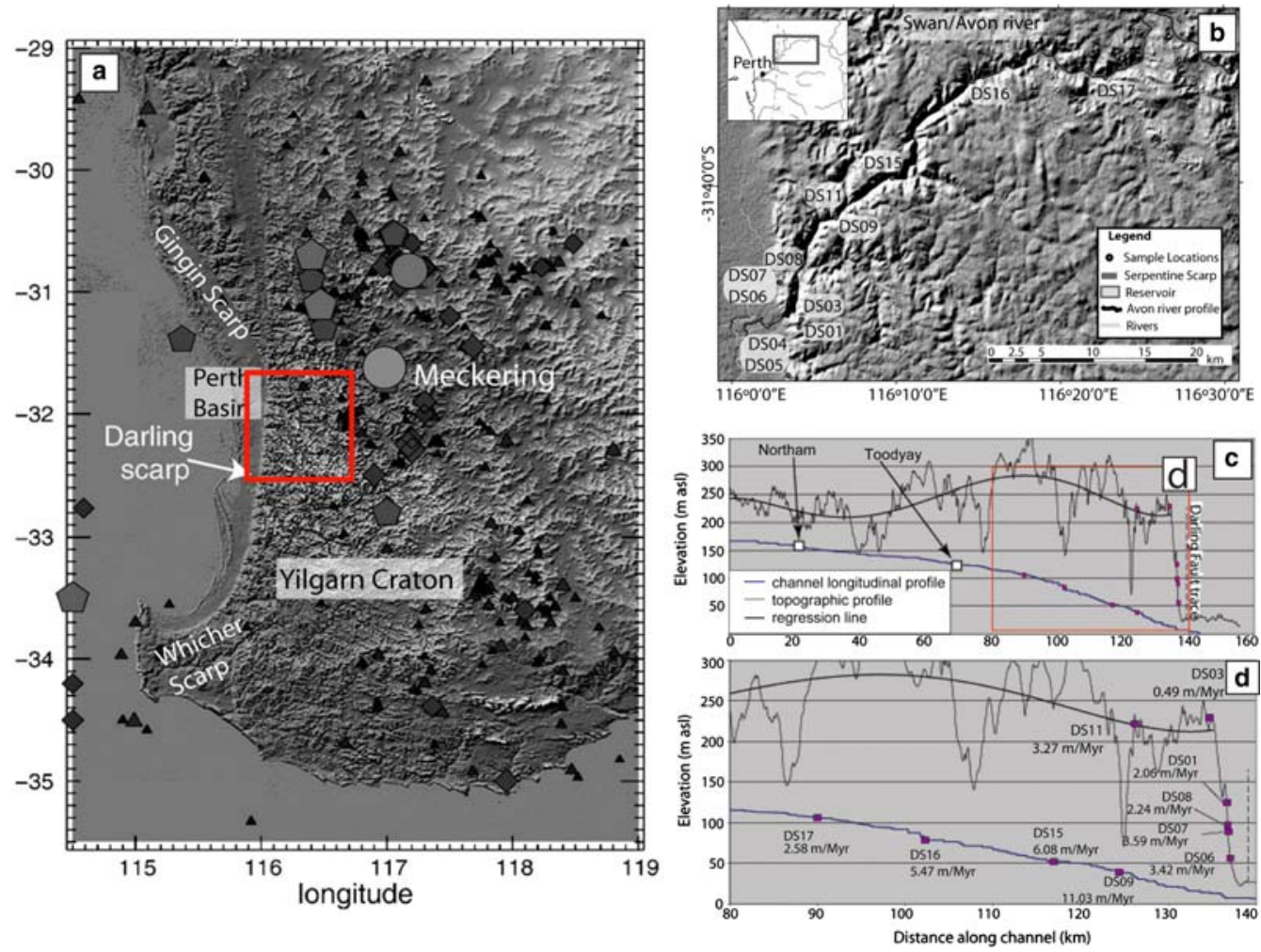

Fig. 5. (a) Seismicity of western Australia, showing absence of earthquakes along the Darling escarpment. (b) Location of cosmogenic nuclide samples (DS01-17) along the Avon river section. (c) Longitudinal profile of the river showing convex-up 'disequilibrium' profile that deviates from a concave-up graded equilibrium profile. (d) Enlargement of box in (c) showing sample locations and erosion rates. The decay of erosion rate estimates in the Avon River away from the range front should be noted (from Jakica et al. 2010).

propagation of knickpoints formed during slow, regional base-level lowering associated with continental-scale tilting (Jakica et al. 2010). In contrast to the northern Australian coastline, sea cliffs are abundant and often result in nearshore elevations of $>50 \mathrm{~m}$ in height (Nullarbor Plain). Offshore islands are small and rare, and bathymetry increases steeply away from the coast. Topographic effects associated with long-wavelength deformation may thus be responsible for shaping several features of the contemporary landscape, including coastline geomorphology and stream profiles.

\section{Intermediate-wavelength $\left(10^{2}-10^{3} \mathrm{~km}\right)$ deformation}

\section{Characteristics}

Regions of intermediate-wavelength (100-1000 $\mathrm{km})$, low-amplitude (100-200 m) topographic undulations have developed in several parts of the continent and are distinct from the long-wavelength signal described above. The southern Australian volcanic field (Joyce 1975) is associated with a zone of subdued regional uplift, with a characteristic uplift of $c .60 \mathrm{~m}$, maximum uplift of $c .240 \mathrm{~m}$, and wavelength of $c .100 \mathrm{~km}$ evidenced by warping of Pliocene and Quaternary beach ridge systems (Wallace et al. 2005; Sandiford et al. 2009). This zone of uplift can be traced for $c .400 \mathrm{~km}$ west from Melbourne, where it bifurcates into the Padthaway and Gambier uplifts (Fig. 3b).

The region encompassing the Flinders Ranges and adjacent basins (Frome, Torrens; Fig. 3) also displays evidence for intermediate-wavelength deformation (Celerier et al. 2005; Quigley et al. 2007c). Plio-Quaternary alluvial fans on the eastern and northwestern side of the ranges are commonly uplifted and incised proximal to the range front (Coats 1973; Sandiford 2003b), with the fanbreaching streams emptying $30-50 \mathrm{~km}$ outboard of the range front in the Frome and Torrens basins (Figs $3 \& 6$ ). On the eastern side of the ranges, 


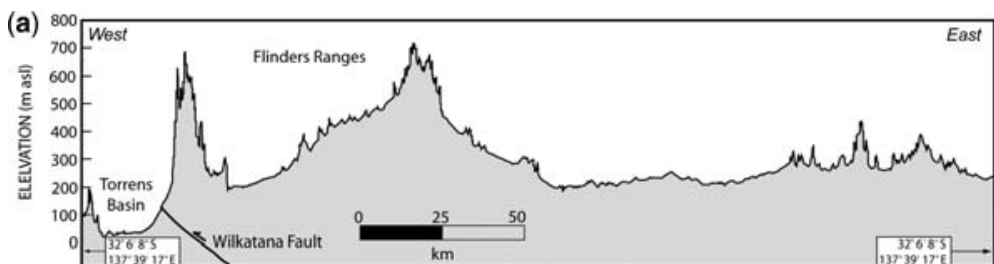

(b)

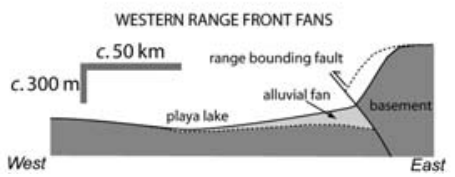

(c)

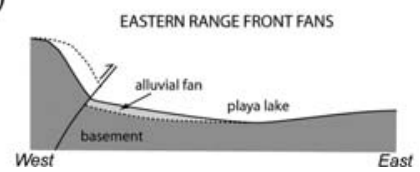

Fig. 6. (a) East-west topographic cross-section across the central Flinders Ranges. Length of section is $275 \mathrm{~km}$. (b) Schematic cross-section of the western range front, showing geometry of basement-alluvium interface. Base of fans dips gently away from ranges distal to range front and towards ranges close to range front, indicative of flexural subsidence in response to loading superimposed on broader scale domal uplift. (c) Schematic cross-section of the eastern range front. Basement-alluvium interface dips gently away from range front, a geometry that Cèlérier et al. (2005) attributed to long-wavelength flexural buckling of the lithosphere in the eastern Flinders Ranges (from Quigley et al. 2007c).

and parts of the western side of the ranges (e.g. Parachilna), the underlying basement-alluvium interface dips gently away from the ranges towards the basins, inconsistent with the architecture of flexurally controlled footwall basins, where the unconformity between the alluvial fans and the underlying basement typically dips towards the ranges (Celerier et al. 2005). The regional distribution of basinward-dipping top-of-basement surfaces implicates a component of low-amplitude (100-200 m), intermediate-wavelength $(c .200 \mathrm{~km})$ regional deformation (Celerier et al. 2005; Quigley et al. 2007c). In other parts of the western side of the ranges (e.g. Wilkatana), the unconformity between the alluvial fans and the underlying basement dips towards the ranges (Quigley et al. 2007c). This implies that the footwall architecture varies along the western range front as a result of differing amounts of flexural footwall subsidence that probably relates to differences in sediment yield and range front faulting histories (Quigley et al. 2007c). The Torrens Basin, which is currently separated from the sea in Spencer Gulf by a sill of only $c .30-40 \mathrm{~m}$ asl, contains no evidence for marine incursions in the form of palaeo-shorelines or marine sediment (Johns 1968). Pliocene sea-level highstands should have encroached into these lowlying regions if the present surface topography was static since the Pliocene, implying that absolute subsidence of the order of several tens of metres must have occurred in this region in the late Neogene following Miocene to Pliocene eustatic sea-level highs (Quigley et al. 2007c).

Intermediate-wavelength topographic development is also evident in the Lake Eyre region. The Eyre basin, with a present-day minimum elevation of $10 \mathrm{~m}$ below sea level (bsl) is confined by a sill at c. $80 \mathrm{~m}$ asl from the Torrens Basin to the south (Fig. 7). This drainage divide is marked by arcuate strandline deposits of the large, late Miocene palaeo-lake Billa Kalina (Callen \& Cowley 1998). At its maximum size of $c .15000 \mathrm{~km}^{2}$ this lake would seem to require a catchment that included much of the present Eyre and Torrens basins. The difference in elevation between the base of the Billa Kalina deposits (c. $120 \mathrm{~m}$ asl) and Lake Eyre (c. $15 \mathrm{~m}$ asl) implies a post-late Miocene topographic inversion of $c .135 \mathrm{~m}$ with a wavelength of c. $250 \mathrm{~km}$ (Sandiford et al. 2009). The Eyre Basin is fringed to the west by the Davenport Ranges. Intermediate-wavelength $(c .50 \mathrm{~km})$ gentle folding is indicated by subtle undulation $(c .200 \mathrm{~m})$ of the top-of-basement surface, currently expressed as an exhumed, warped and incised fossil planation surface forming the Mt Margaret Plateau on the top of the Davenport Ranges (Wopfner 1968; Johnson 2004). The plateau surface contains Cretaceous gravel lags at elevations of $400 \mathrm{~m}$ asl within the Davenport ranges that correlate with rocks exposed at elevations of $<150 \mathrm{~m}$ asl along the eastern range front, indicating $>250 \mathrm{~m}$ of post-Cretaceous uplift. Wopfner (1968) attributed this to Quaternary fault-related uplift (see next section); however, the broad wavelength of the doming suggests that it may relate to gentle folding.

\section{Origin and rates}

Although a few faults appear to displace basalts of the Newer Volcanics (e.g. the Rowsley Fault), significant episodes of faulting between $c$. 6-4 Ma (Paine et al. 2004) and 2-1 Ma (Sandiford 2003a) 

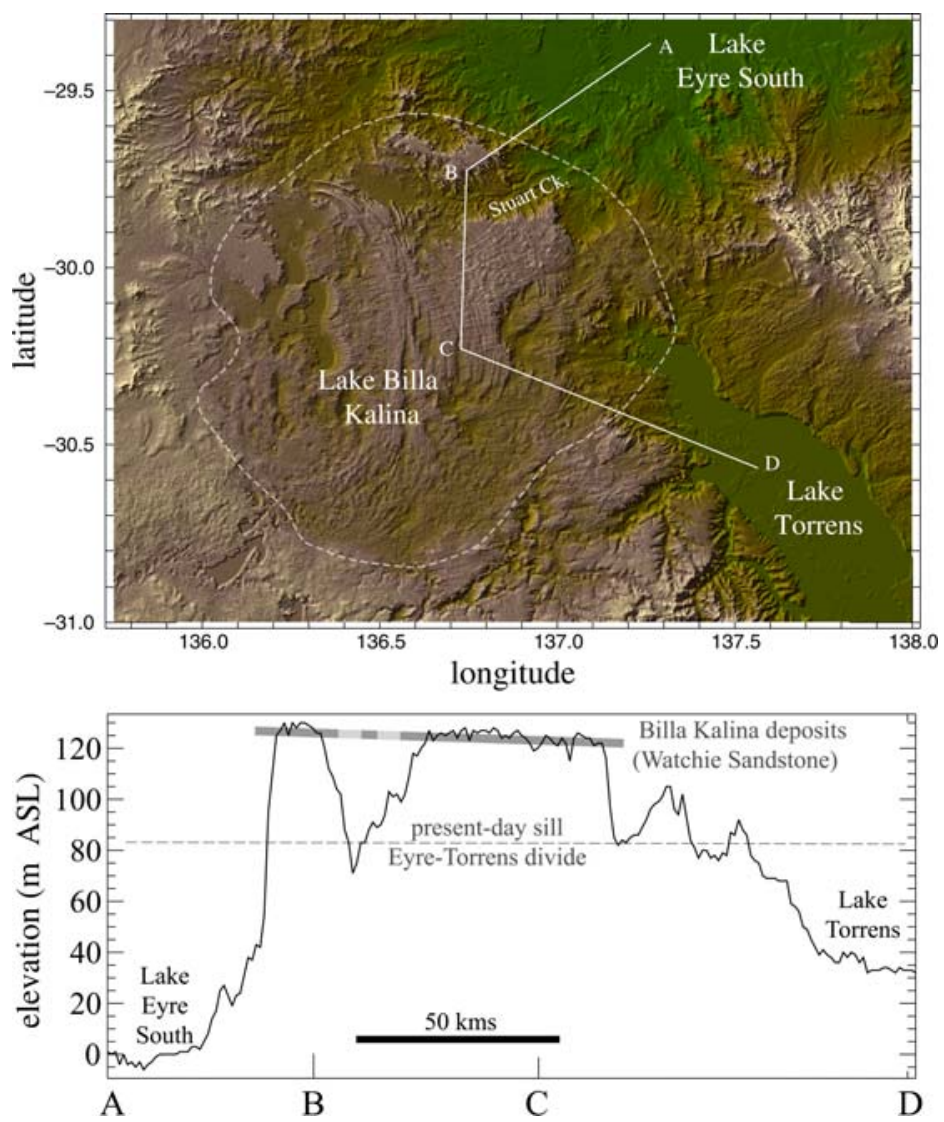

Fig. 7. (a) Shaded relief image of Billa Kalina Basin, South Australia, showing distinctive arcuate palaeo-shoreline features of Lake Billa Kalina of probable Miocene age. The inferred approximate maximum extent of the lake is indicated by the dashed line, based on limits of relict palaeo-shorelines. (b) Topographic profile along line A-B-C-D. It should be noted that Lake Billa Kalina is now perched on the present drainage divide between the Torrens and Eyre Basins, implying significant topographic inversion since the lake formation (from Sandiford et al. 2009).

do not appear to have significantly affected the southern Australian volcanic field. The Padthaway and Gambier uplifts are not associated with any significant faulting and the Padthaway uplift axis is almost parallel to the regional NW-SE compression direction defined by in situ stresses (Fig. 1). These observations imply that uplift is unlikely to be associated with contractional tectonic faulting or buckling at these locations. Known neotectonic faults from the Murray Basin (e.g. the Morgan, Hamley and Danyo Faults, and faults underlying the Neckarboo and Iona Ridges) universally strike towards the north and NE (Sandiford 2003b). The coincidence of mild yet regionally extensive basaltic volcanism with uplift of the volcanic field led Demidjuk et al. (2007) to conclude that surface uplift was driven by upper mantle upwelling associated with small-scale, edge-driven convection beneath the Australian plate. Uplift of Quaternary beach ridges on the Mount Gambier Coastal Plain over the last $780 \mathrm{ka}$ indicates a surface uplift rate of c. $75 \mathrm{~m} \mathrm{Ma}^{-1}$ (Belperio 1995). Associated gentle subsidence in the more internal parts of the Murray Basin several hundred kilometres to the north is interpreted to have occurred above the downwelling part of the convection circuit (Demidjuk et al. 2007).

Conversely, the intermediate-wavelength pattern of deformation associated with Flinders Ranges and surrounding anomalously low basins (such as the Torrens and Frome basins) has been attributed to lithospheric-scale $\left(10^{2} \mathrm{~km}\right)$ tectonically induced buckling (Celerier et al. 2005). This interpretation is based both on the topography of the top-ofbasement surface and the observed positive coherence between topography and Bouguer gravity fields, implying that the Flinders Ranges are not supported by a crustal root but rather have risen 
in response to lithospheric folding. The Indian Ocean provides an analogous system, whereby buckling of the oceanic lithosphere beginning at around $8 \mathrm{Ma}$ ago has been attributed to increases in intraplate stress levels caused by an increase in plate forcing induced by the rise in the Himalayan-Tibetan orogen at this time (e.g. Martinod \& Molnar 1995). Similar scale buckling of the continental lithosphere perpendicular to the regional $\sigma_{\text {Hmax }}$ is associated with localized seismicity in intraplate India (Vita-Finzi 2004). For the Flinders Ranges, the notion of lithospheric-scale buckling along a roughly north-south axis is consistent with the prevailing east-west $\sigma_{\mathrm{Hmax}}$ trend in this part of the continent.

The pattern of topography in the Lake Eyre region is more puzzling. The bullseye-shaped Eyre topographic depression is similar to other intracontinental basins associated with mantle downwelling (e.g. Hudson Bay, Canada; Wanganui Basin, New Zealand) (Mitrovica et al. 1989; Stern et al. 1992). However, the presence of folded and faulted Miocene alluvial strata along the western flank of Lake Eyre (Waclawik et al. 2008) and the longwavelength folding of the basement surface in the Davenport Ranges suggest that regional compression has affected this region and thus provides an equally feasible mechanism for intermediatewavelength deformation (e.g. Celerier et al. 2005; Vita-Finzi 2004).

\section{Geomorphological implications}

Intermediate-wavelength deformation has influenced the geomorphological evolution of uplands, basins, and alluvial systems at the sites described above. Uplift associated with the Padthaway high is suggested to have dammed the Murray River, forming a large palaeo-lake (Lake Bungunnia) several hundred kilometres to the north (Fig. 3b; Stephenson 1986). Lake formation and subsequent abandonment, and the consequent changes in stream base level, are likely to have had a strong influence on stream gradient evolution and aggradation-dissection patterns. Intermediate-wavelength deformation in south-central Australia has influenced the geomorphological evolution of broad upland systems (Flinders and Davenport Ranges) and adjacent basins (Eyre, Frome, Torrens) through effects on the spatial and temporal evolution of regional topography. The migration of a major basin depocentre from Billa Kalina to Eyre has resulted in significant drainage reversals in the region; for instance, former Billa Kalina southwestwardyounging shorelines (formed by shoreline retreat) are now incised by east- and NE-flowing streams (Fig. 7). Broad uplift of the Flinders Ranges and Davenport Ranges relative to Lakes Frome,
Torrens and Eyre has shifted the location of depocentres further from the range fronts, resulting in the incision of alluvial fans proximal to the ranges and final deposition of sediment more distal from the ranges (Williams 1973; Quigley et al. 2007c; J. Bowler, pers. comm.). Marine shoreline evolution has also been strongly influenced by intermediatewavelength deformation. The lack of marine sedimentation at elevations of $30-40 \mathrm{~m}$ between Torrens Basin and Spencer Gulf (Fig. 3) contrasts with the presence of Pliocene strandlines at $>200 \mathrm{~m}$ asl in parts of the Murray Basin, implying a regime characterized by both long-wavelength post-Pliocene subsidence and uplift. Continued slow subsidence between Spencer Gulf and Torrens coupled with sea-level rise may allow northward penetration of the sea into this region (Quigley et al. 2007c).

\section{Short-wavelength $\left(10^{1} \mathrm{~km}\right)$ deformation}

\section{Characteristics}

Insights into short-wavelength, fault-related deformation have been obtained from historical seismicity and faulting and the prehistoric 'neotectonic' geological record of faulting. Much of Australia's seismicity is concentrated into four distinct zones; the SW, NW, Flinders and SE seismic zones (Fig. 8). Calculated earthquake focal mechanism solutions indicate reverse faulting associated with roughly NW-SE horizontal compression throughout the SE seismic zone (Allen et al. 2005; Nelson et al. 2006). Flinders seismic zone mechanisms indicate strike-slip and reverse mechanisms with a broadly east-west horizontal compression (Hillis \& Reynolds 2000; Clark \& Leonard 2003; Hillis \& Reynolds 2003). SW seismic zone mechanisms indicate reverse faulting mechanisms with eastwest-oriented maximum horizontal stress (Denham et al. 1979; Clark \& Leonard 2003). The NW seismic zone is typified by a NW-SE-oriented maximum horizontal stress orientation and predominantly strike-slip mechanisms (Hillis et al. 2008).

Seven instrumentally recorded earthquakes have produced surface ruptures, all occurring within the last 40 years (Fig. 9a). Earthquakes ranged in magnitude from 5.6 to 6.8 , and produced scarps of $3.5-37 \mathrm{~km}$ length and 0.4-2.5 m height (Clark \& McCue 2003). All historical scarps contain a dominant reverse-slip component with subsidiary oblique-slip. However, all historical fault scarps occurred in farming and/or grazing areas with low relief and thus their geomorphological impacts on the natural landscape have been short-lived, with rapid scarp degradation (Machette et al. 1993; Clark \& McCue 2003; Crone et al. 2003). 


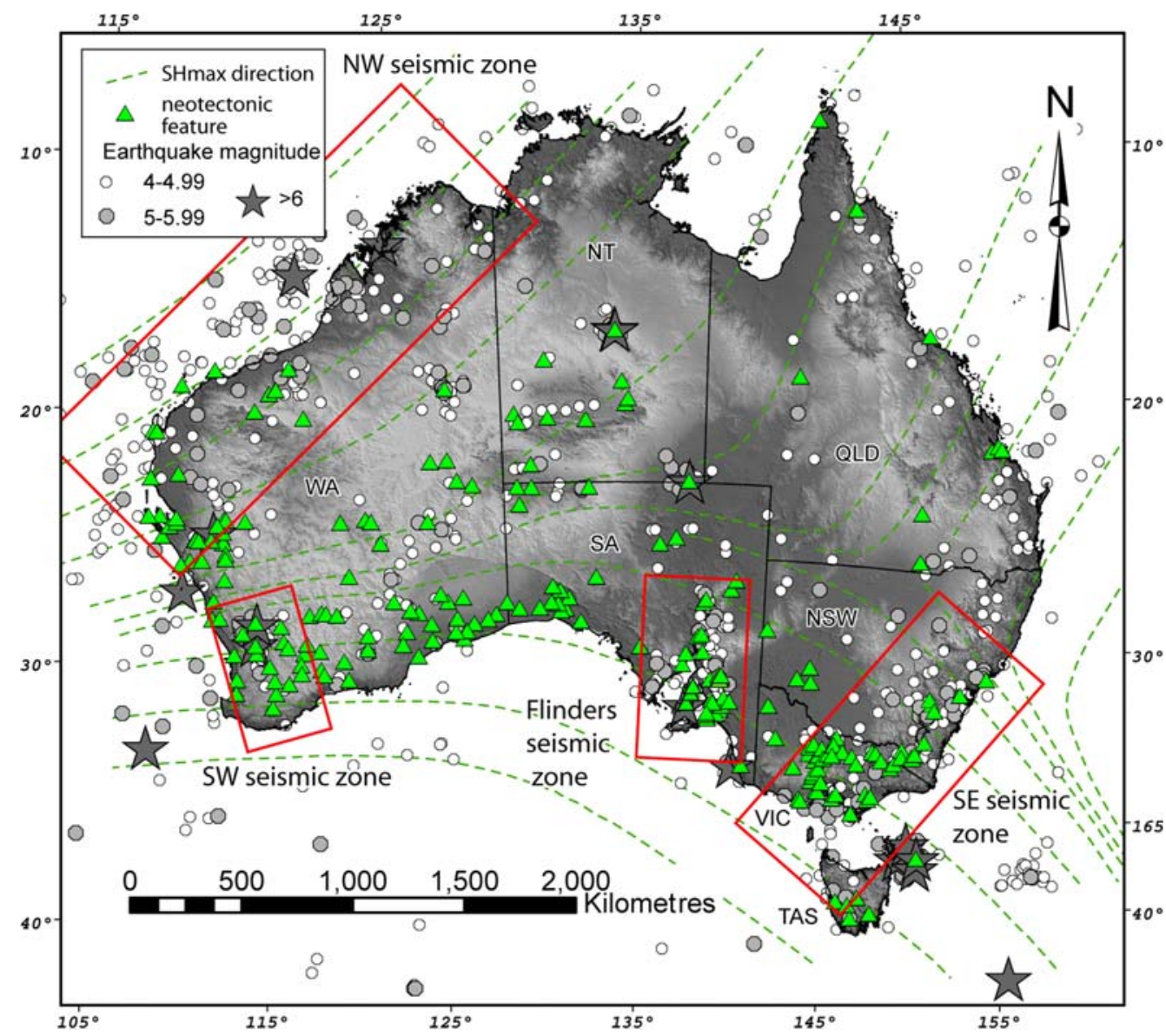

Fig. 8. Distribution of $M>4$ historical earthquake epicentres and identified neotectonic features in Australia. Earthquake epicentre and neotectonics data are courtesy of Geoscience Australia. Clustering of earthquake epicentre distributions indicates four seismic zones; NW seismic zone, SW seismic zone, Flinders seismic zone, and SE seismic zone. Maximum horizontal stress directions $\left(\sigma_{\mathrm{Hmax}}\right)$ after Hillis \& Reynolds (2003) are shown.

Geological studies have identified several hundred faults across the continent with demonstrable Pliocene and/or Quaternary displacements (Fig. 9; Clark \& McCue 2003; Crone et al. 2003; Sandiford 2003b; Twidale \& Bourne 2004; Clark 2006, 2009; Quigley et al. 2006; Clark et al. 2010). The clearest evidence for active tectonic deformation in the Australian landscape is found in the fault-related landscapes around upland systems in SE and south-central parts of the continent (Sandiford 2003b). The Flinders and Mount Lofty Ranges of South Australia are bounded to the east and west by reverse faults that thrust Proterozoic and/or Cambrian basement rocks above Quaternary sediment (Fig. 9c-f). Faults in this region with documented Pliocene to Quaternary displacements include the Wilkatana, Burra, Milendella, Para, Paralana, Willunga, Cambrai, Morgan,
Gawler, Clarendon, Eden, Bremer, and Ediacara (Fig. 2a; Binks 1972; Williams 1973; Bourman \& Lindsay 1989; Sandiford 2003b; Quigley et al. 2006). Fault-propagation folding is well developed in Miocene strata within the footwall of the Willunga and Gawler Faults (Fig. 9c; Lemon \& McGowran 1989; Green 2007). The Barrier Ranges are flanked to the west by the Mundi Mundi and Kantappa Faults, both which displace late Quaternary strata (Quigley et al. 2006). The eastern edge of the Davenport Ranges is defined by the Mt Margaret and Levi Faults, which have been interpreted to have tens to hundreds of metres of Quaternary offset (Wopfner 1968). Miocene sediments forming the adjacent Lake Eyre alluvial plain have also been folded and faulted (Waclawik et al. 2008). The Eyre Peninsula consists of a series of en echelon reverse faults that 
displace Miocene to Quaternary stratigraphy (Fig. 9b; Miles 1952; Dunham 1992; Hutton et al. 1994; Crone et al. 2003). A series of scarps on the Yorke Peninsula have been attributed to Quaternary faulting as they offset a Pleistocene calcrete horizon (Crawford 1965). In SE Australia, upland systems such as the Otway and Strzelecki Ranges have similarly been affected by Pliocene to Quaternary reverse faulting. On the northern flanks of the Otway Range, in southern Victoria, the remnants of a Pliocene strandplain rise $c .120 \mathrm{~m}$ over a series of ENE-WSW-trending faults and monoclines to elevations of $c .250 \mathrm{~m}$ (Sandiford 2003a; Sandiford et al. 2004). Along with its correlatives in the Murray and Gippsland Basins (Holdgate et al. 2003; Wallace et al. 2005), this strandplain developed during falling sea levels following a $6 \mathrm{Ma}$ highstand at $c .65 \mathrm{~m}$ above present-day sea level (Brown \& Stephenson 1991), implying almost $200 \mathrm{~m}$ of fault-related tectonic uplift. In the Eastern Highlands of northern Victoria, Palaeozoic gneiss has been thrust some $160 \mathrm{~m}$ over Quaternary alluvium along the Tawonga Fault (Beavis 1960; Hills 1975). Elsewhere in the highlands, Palaeozoic rocks are similarly thrust over Miocene and younger strata along the Khancoban-Yellow Bog, Kiewa, Adaminaby, Lake George, and Shoalhaven Faults (e.g. Beavis \& Beavis 1976; Abel 1985; Sharp 2004; Twidale \& Bourne 2004). Uplift along the Cadell Fault has been dated as latest Pleistocene (Bowler \& Harford 1966; Bowler 1978; Rutherfurd \& Kenyon 2005; Clark et al. 2007). The Waratah Fault at Cape Liptrap in SE Victoria has displaced a last interglacial (c. $125 \mathrm{ka})$ marine terrace by up to $5.1 \mathrm{~m}$ (Gardner et al. 2009). The Lake Edgar Fault in Tasmania has incurred three surfacerupturing events with average displacements of c. $2.5-3 \mathrm{~m}$ in the last $c$. $50 \mathrm{ka}$, with the most recent event occurring at $c$. 18-17 ka (Clark et al. 2010). Kinematic studies of many of these faults indicate that faulting occurred in response to roughly east-west- to SE-NW-oriented palaeo $\sigma_{\text {Hmax }}$ consistent with focal mechanism and contemporary stress data, implying that Neogene to Quaternary faulting is linked with the modern tectonic regime (Sandiford 2003b; Quigley et al. 2006; Gardner et al. 2009).

The relationship between Neogene to Quaternary faulting and uplifted topography is less clear in western Australia. Although some of the largest recorded earthquakes and the largest moment release occurs in the SW seismic zone (Leonard 2008; Braun et al. 2009), the only feature with appreciable relief in this part of the continent is the Darling Scarp, which is historically aseismic and contains no evidence for Quaternary displacement (Sandiford \& Egholm 2008). Faults with demonstrated Quaternary displacement, including the Meckering (Fig. 9a), Calingiri, Cadoux, Hyden, Lort River, Dumbleyung and Mt Narryer Faults, are associated with discrete scarps $<2.5$ $5 \mathrm{~m}$ high (Williams 1979; Gordon \& Lewis 1980; Lewis et al. 1981; Crone et al. 2003; Twidale \& Bourne 2004; Estrada 2009). The absence of evidence for continuing fault-related relief generation on geological time scales in this part of the continent implies that seismic activity has only recently commenced or that, unlike SE and south-central Australia, is not localized on discrete structures at geological time scales. The sparse palaeoseismological dataset available is most consistent with the latter interpretation.

In the NW seismic zone, a series of asymmetric anticlines (e.g. Cape Range, Barrow, Rough Range anticlines) have developed as fault propagation folds above blind reverse faults (Hocking 1988; Hillis et al. 2008). The growth of fault propagation anticlines is generally dated as Miocene and younger in the Carnarvon Basin (e.g. Barber 1988; Hearty et al. 2002). Concentrations of earthquake epicentres (Geoscience Australia online earthquake catalogue: www.ga.gov.au), and emerged Pleistocene marine terraces on the Cape Range anticline and anticlinal folds in offshore Plio-Quaternary seafloor sediments (van de Graaff et al. 1976), indicate that deformation has continued to the present.

All of the faults described above for which kinematics can be resolved involve either purely dip-slip reverse movement or oblique-reverse movement, indicating that crustal thickening and uplift occurs across the Australian continent. Estimates of Quaternary earthquake magnitudes (M), based on fault rupture lengths, single-event displacements and inferred ranges of hypocentral rupture depth, range from $\mathrm{M}=5.8$ to 7.3 (Clark \& McCue 2003; Quigley et al. 2006). The data are consistent with magnitude estimates for the largest recorded Australian earthquakes (Meeberiee, WA 1941, $M=7.3$; Meckering, WA 1968, $M=6.8$; Tennant Creek, NT 1988; $M=6.7)$. Estimates of surfacerupturing earthquake recurrence intervals from faults with multiple displacements range from 1 in $22 \mathrm{ka}$ to $\geq 1$ in $83 \mathrm{ka}$ (Crone et al. 2003; Quigley et al. 2006; Clark et al. 2008).

\section{Origin and rates}

Seismic strain rates have been calculated for the Australian continent using historical seismicity. Assuming a maximum earthquake magnitude of $M=7$, the maximum seismic strain rate calculated for Australia's seismic zones is $c .10^{-16} \mathrm{~s}^{-1}$, and the continent-averaged strain rate is no more than c. $10^{-17} \mathrm{~s}^{-1}$ (Celerier et al. 2005; Leonard 2008; Braun et al. 2009). A bulk strain rate of $10^{-16} \mathrm{~s}^{-1}$ in uniaxial compression implies a total shortening 

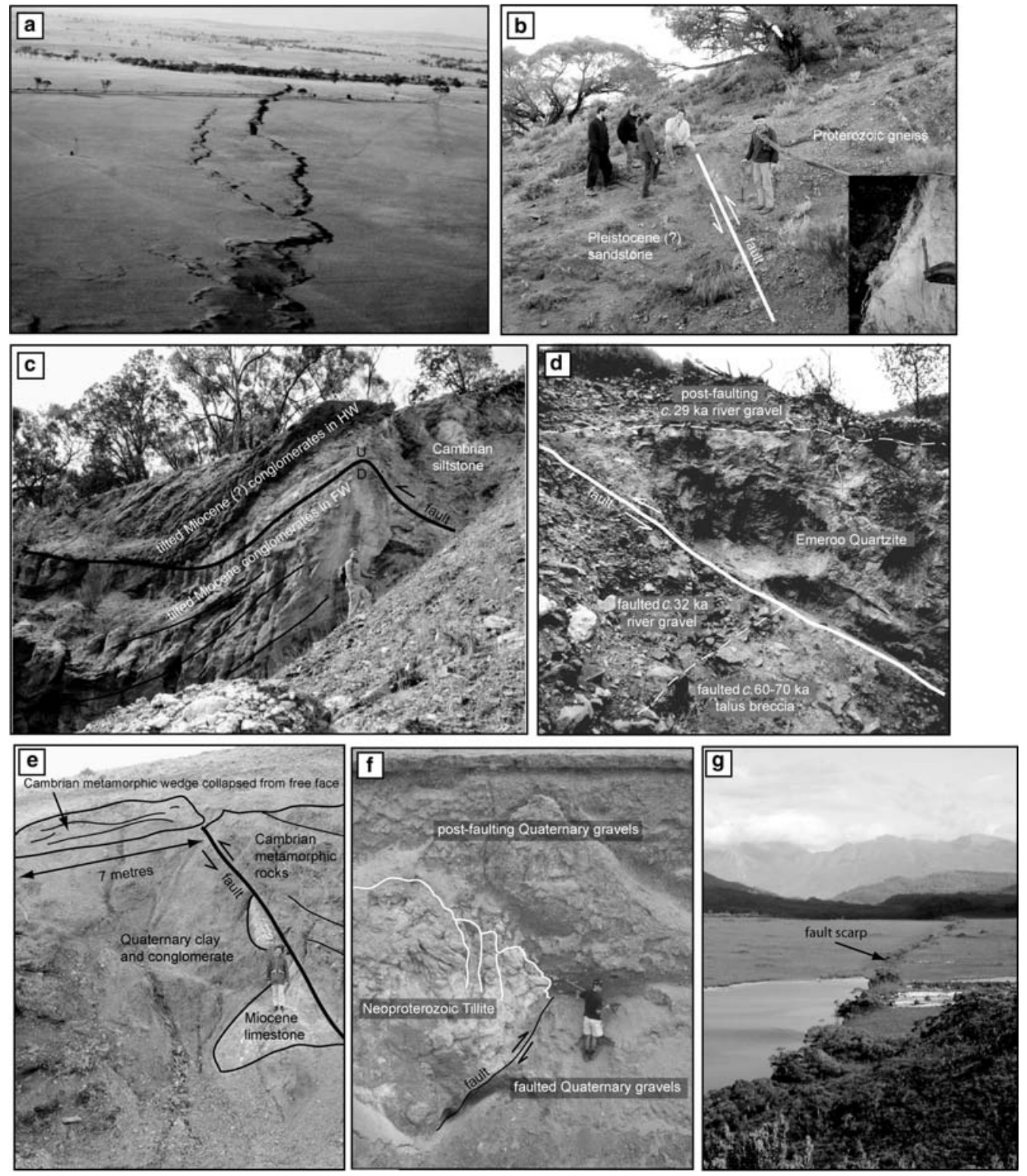

Fig. 9. Field photographs of selected historical and prehistoric faults across the Australian continent, from west to east. (a) Meckering Fault scarp in Western Australia, formed on 14 October 1968 during the $\mathrm{M}_{\mathrm{S}} 6.8$ Meckering earthquake. View is to the south. The fault has a westward heave of $2.44 \mathrm{~m}$, a dextral lateral component of movement of $1.54 \mathrm{~m}$, and a throw of $1.98 \mathrm{~m}$ (Dentith et al. 2009). Photograph courtesy of K. McCue and the Australian Earthquake Engineering Society. (b) Murninnie Fault on the eastern Eyre Peninsula, South Australia. View to the south. The fault plane is oriented $170^{\circ}$, dips $60^{\circ}$ to the west, and thrusts Proterozoic basement gneiss over Pleistocene(?) sandstones (main image) and Pliocene clay (inset), indicating that the most recent event occurred no earlier than the Pleistocene. (c) Gawler Fault east of the Mt Lofty Ranges, South Australia. View to the east. The fault plane strikes NNE, dips $40-60^{\circ}$ to the east, and thrusts Cambrian siltstone over late Miocene(?) gravels. Fault-propagated folding in the Miocene strata is evident from the folded bedding. (d) Wilkatana Fault in the central Flinders Ranges, South Australia. View to the north. The fault strikes NNW, dips $40-60^{\circ} \mathrm{E}$, and thrusts Neoproterozoic quartzite over Pleistocene gravels with a reverse-oblique total slip of up to $15 \mathrm{~m}$ (Quigley et al. 2006). The last major earthquake on this fault occurred c. 30 ka ago. (e) Milendella Fault in the eastern Mt Lofty ranges, South Australia. View to the south. The fault strikes north, dips $c .50^{\circ} \mathrm{W}$, and juxtaposes metamorphosed Cambrian rocks in the hanging wall with a footwall composed of a 
of c. $250 \mathrm{~m} \mathrm{Ma}^{-1}$ across a c. $100 \mathrm{~km}$ wide zone, such as the Flinders seismic zone (Sandiford \& Quigley 2009). Such shortening could be accounted for with slip on 10 faults each accommodating about $25 \mathrm{~m}$ of horizontal slip per million years, equating to $25 \mathrm{~m} \mathrm{Ma}^{-1}$ of vertical uplift for $45^{\circ}$ dipping faults (Flinders Fault dips range from c. 30 to $80^{\circ}$; Celerier et al. 2005; Quigley et al. 2006). Accounting for some aseismic slip, actual fault slips may be even larger, and suggest slip rates to the closest order of magnitude in the range between $10^{1}$ and $10^{2} \mathrm{~m} \mathrm{Ma}^{-1}$ in the most active parts of the continent.

Fault slip rates derived from cumulative displacements of Pliocene and Quaternary sediment in SE and south-central Australia range from 20 to $150 \mathrm{~m} \mathrm{Ma}^{-1}$ (Sandiford 2003b; Quigley et al. 2006). Displacement of Neogene strata in the Otway Ranges has accumulated in the last 5-6 Ma (Sandiford et al. 2004) giving time-averaged displacement on bounding faults $c$. $40-50 \mathrm{~m} \mathrm{Ma}^{-1}$. Penultimate earthquakes on the historically active Marryat Creek and Meckering Faults occurred $>100 \mathrm{ka}$ ago, equating to rates of $<10-35$ $\mathrm{m} \mathrm{Ma}^{-1}$ (Machette et al. 1993). The Rosedale Fault in Gippsland is purported to have experienced a slip rate of $50-80 \mathrm{~m} \mathrm{Ma}^{-1}$ over the Early to Middle Pleistocene (Holdgate et al. 2003). However, fault slip rates determined from single fault exposures are difficult to assess because of the tendency of intracontinental faulting to cluster in time and space, resulting in under- or overestimation depending on the time of the last event (Crone \& Machette 1997; Crone et al. 1997, 2003). For example, faults in the Wilkatana area of the central Flinders Ranges incurred upwards of $15 \mathrm{~m}$ of cumulative slip as a result of three or more earthquakes since $c .67 \mathrm{ka}$ ago, equating to a c. $67 \mathrm{ka}$ to Recent rate $\left(\right.$ c. $\left.225 \mathrm{~m} \mathrm{Ma}^{-1}\right)$ that is significantly more rapid than the Pliocene to Recent rate $\left(20-50 \mathrm{~m} \mathrm{Ma}^{-1}\right)$.

There is some indication that the temporal clustering behaviour emerging from single fault studies may be symptomatic of a larger picture of the more or less continuous tectonic activity from late Miocene to recent being punctuated by 'pulses' of activity in specific deforming regions. For example, major deformation episodes are constrained to the interval 6-4 Ma in SW Victoria (Paine et al. 2004) and 2-1 Ma in the Otway Ranges (Sandiford 2003a). An episode of deformation ceased at 1.0 Ma in the offshore Gippsland Basin although it continued onshore until $c .250 \mathrm{ka}$ (Holdgate et al. 2003). Holdgate et al. (2008) presented evidence from the SE Highlands that resurrected the idea of a punctuated post-Eocene Kosciusko Uplift event (see Browne 1967) that continued into the Late Pliocene and possibly the Pleistocene. It is possible that this event might relate to the pulse of deformation seen in SE Australian offshore basins in the interval 10-5 Ma associated with the reorganization of the crustal stress field to its present configuration (Dickinson et al. 2001, 2002; Sandiford et al. 2004; Hillis et al. 2008). The Lake George Fault near Canberra (Singh et al. 1981; Abel 1985), and faults of the Lapstone Structural Complex near Sydney (Fig. 3) may also have accumulated much of their Neogene displacement in this event (Clark 2010). Indeed, palaeomagnetic data indicate that folding and uplift relating to the Lapstone Structural Complex had largely ceased by the late Pliocene (Bishop et al. 1982 with age recalculated by Pillans 2003). In contrast, Gardner et al. (2009) obtained slip rates on the Waratah Fault of $10-40 \mathrm{~m} \mathrm{Ma}^{-1}$ for displacements across both $125 \mathrm{ka}$ and Pliocene marine terraces, so indicating that there may be some fault systems that do not exhibit highly variable long-term slip rates.

The factors that localize seismic activity and associated fault-related deformation within the Australian continent have been addressed in a number of studies. Fault reactivation of pre-existing structural weaknesses such as ancient fault zones almost certainly plays a fundamental role (Crone et al. 2003; Dentith \& Featherstone 2003; Quigley et al. 2006). Faults commonly occur along geological boundaries such as inherited lithotectonic boundaries (e.g. Wilkatana and Roopena-Ash Reef Faults within the Lake Torrens Rift Zone) and topographic boundaries such as range fronts (Flinders and Mt. Lofty Ranges). It is unclear how surface topography influences near-surface fault

Fig. 9. (Continued) sliver of Lower Miocene limestone and a Quaternary gravel and clay sequence that elsewhere contains the Brunhes-Matuyama palaeomagnetic reversal at $c .780 \mathrm{ka}$ BP (Sandiford 2003b). A metamorphic foliation can be traced across a wedge of colluvial material derived from the hanging wall immediately above the footwall, implying that this colluvium may have resulted from post-seismic collapse of the hanging wall with a fault displacement of up to $7 \mathrm{~m}$. The total post-Early Miocene throw on the Milendella Fault is at least c. 60-90 m (Sandiford 2003b). (f) Burra Fault east of the central Flinders Ranges, South Australia. View to north. The fault strikes north, dips $c .30^{\circ} \mathrm{W}$, and thrusts Neoproterozoic tillite over Quaternary gravels. The total fault displacement is $c .4 \mathrm{~m}$ and predates $c .83 \mathrm{ka}$ (Quigley et al. 2006). (g) Lake Edgar Fault scarp and related geomorphological features in southern Tasmania. View to the south. The fault cross-cuts a periglacial alluvial fan and has incurred three surface-rupturing events with average displacements of $c .2 .5-3 \mathrm{~m}$ in the last $c .50 \mathrm{ka}$, with the most recent event occurring at $c .18-17 \mathrm{ka}$ (from Clark et al. 2010). 
geometry, if at all. However, significant along-strike variations in fault dip are common (e.g. Milendella Fault, Wilkatana Fault).

Celerier et al. (2005) showed how variations in both absolute abundance and depth of heatproducing elements provide a plausible thermal control on lithospheric strength that helps localize deformation in the Flinders Ranges. The Flinders Ranges form part of a zone of anomalous surface heat flow (Neumann et al. 2000), with an average surface heat flow of $85 \mathrm{~mW} \mathrm{~m}^{-2}$ reflecting unusually elevated heat production in the Proterozoic basement. Celerier et al. (2005) concluded that the uppermost mantle beneath the Flinders seismic zone may be $50-100{ }^{\circ} \mathrm{C}$ hotter than surrounding zones because of the distribution of heat production within the crust, thus providing a thermally weak zone that is prime for focusing deformation. Sandiford \& Egholm (2008) argued that the general correspondence between elevated earthquake activity and proximity to the edge of the continent indicates that thermal effects associated with the ocean-continent transition may also help control the pattern of active deformation in the SW seismic zone. They showed that the effects of steady-state lateral heat flow across transitional lithosphere can produce a weakening effect $100-$ $200 \mathrm{~km}$ inboard of the ocean-continent transition. The anisotropic distribution of intraplate deformation is thus best explained by focusing of far-field stress into pre-existing fault zones, regions of enhanced crustal heat flow, craton boundaries, and regions associated with Moho temperature variations (Sandiford \& Egholm 2008).

\section{Geomorphological implications}

Recurring earthquake activity has resulted in several hundreds of metres of fault displacement in parts of SE Australia, such as the Flinders, Mt Lofty, and Otway Ranges (Bourman \& Lindsay 1989; Tokarev et al. 1999; Sandiford 2003a, b) and in parts of the Eastern Highlands (Hills 1975; Abel 1985; Sharp 2004) over the last 5-10 Ma. Quigley et al. (2007b) suggested that, although fault slip rates are modest compared with those of active faults in plate boundary settings, rates of relative surface uplift (i.e. uplift of mountain summit surfaces relative to adjacent piedmonts) may be comparable with those of more tectonically active environments because of the extremely low rates of bedrock erosion in Australian uplifted terrains. For instance, summit surfaces in the central Flinders Ranges have been uplifted relative to flanking piedmonts by more than $12 \mathrm{~m}$ in the last $70 \mathrm{ka}$, equivalent to a rate of $c .170 \mathrm{~m} \mathrm{Ma}^{-1}$, as a result of activity on range bounding faults. If such rates were sustained over longer time-scales, the present-day relief characterizing much of the Flinders Ranges could have been created in as little as $3 \mathrm{Ma}$. Taking into account the intermittent nature of faulting in Australia, Sandiford $(2003 \mathrm{~b}$ ) and Quigley et al. (2006) suggested that 30-50\% of the present-day elevation of the Flinders Ranges relative to adjacent piedmonts has developed in the last $5 \mathrm{Ma}$. Inter-seismic subsidence may have played a role in the depression of topography along the western Flinders Range front, where the Torrens Basin has subsided several tens of metres since the terminal Miocene (Quigley et al. 2007c). At certain time intervals, some Australian uplands may thus have been uplifted more than mountain belts in tectonically active plate boundary settings such as New Zealand, the Cascadia accretionary margin, and Taiwan because the latter are balanced by rapid rates of erosion and may thus be in topographic steady state (Willet \& Brandon 2002), whereas rock uplift has occasionally exceeded erosion in isolated, tectonically active, semi-arid to arid parts of Australia (e.g. Quigley et al. 2007b).

Coseismic surface displacements can be demonstrated to have exerted an influence on the evolution of many Australian stream systems and, consequently, intra-catchment relief. Surface rupturing along the Wilkatana Fault in the Flinders Ranges differentially uplifted the upstream reach of stream-beds, forming waterfalls (knickpoints) in longitudinal stream profiles (Quigley et al. 2006). Subsequent headward retreat of knickpoints at rates of $>100 \mathrm{~m} \mathrm{Ma}^{-1}$ into catchment systems was invoked to explain the valley-in-valley geomorphology upstream of the Wilkatana Fault (Quigley et al. 2007a). Stream incision rates are similar to bedrock uplift rates, implying that fault-generated uplift has played a major role in modulating intracatchment relief production rates, presumably as a result of tectonic increases in stream profile steepness and stream erosive power.

Coseismic stream damming is evident at a number of sites across Australia. Perhaps the most spectacular example is found in the Echuca district of Victoria, where Late Pleistocene surface rupturing along the Cadell Fault diverted and temporarily dammed the flow of the Murray River, forming Lake Kanyapella (Bowler \& Harford 1966; Bowler 1978; Rutherfurd \& Kenyon 2005; Stone 2006). The river eventually formed northern and southern drainages that deflected around the uplifted fault block (Bowler \& Harford 1966; Rutherfurd \& Kenyon 2005; Clark et al. 2007). The lower Murray River is inferred to have once flowed NW continuously across the Mt Lofty Ranges along what is now the Broughton River, depositing sediments into the Broughton delta in the Spencer Gulf [Williams \& Goode 1978; but see also Harris et al. (1980) for a contrary viewpoint]. Post-Eocene tectonic uplift of 
the Mt Lofty Ranges is inferred to have diverted the Murray to the south, forming the conspicuous modern-day diversion adjacent to the Morgan Fault (Williams \& Goode 1978). Coseismic ponding of streams occurred along the Ash Reef Fault in the Eyre Peninsula (Hutton et al. 1994).
Coseismic ground shaking has also played a role in shaping Australia's geomorphology. Coseismic landslides have been identified in the Flinders Ranges (Quigley et al. 2007a) and are interpreted as major contributors to catchment sediment fluxes throughout the region. Quigley et al. (2007a)
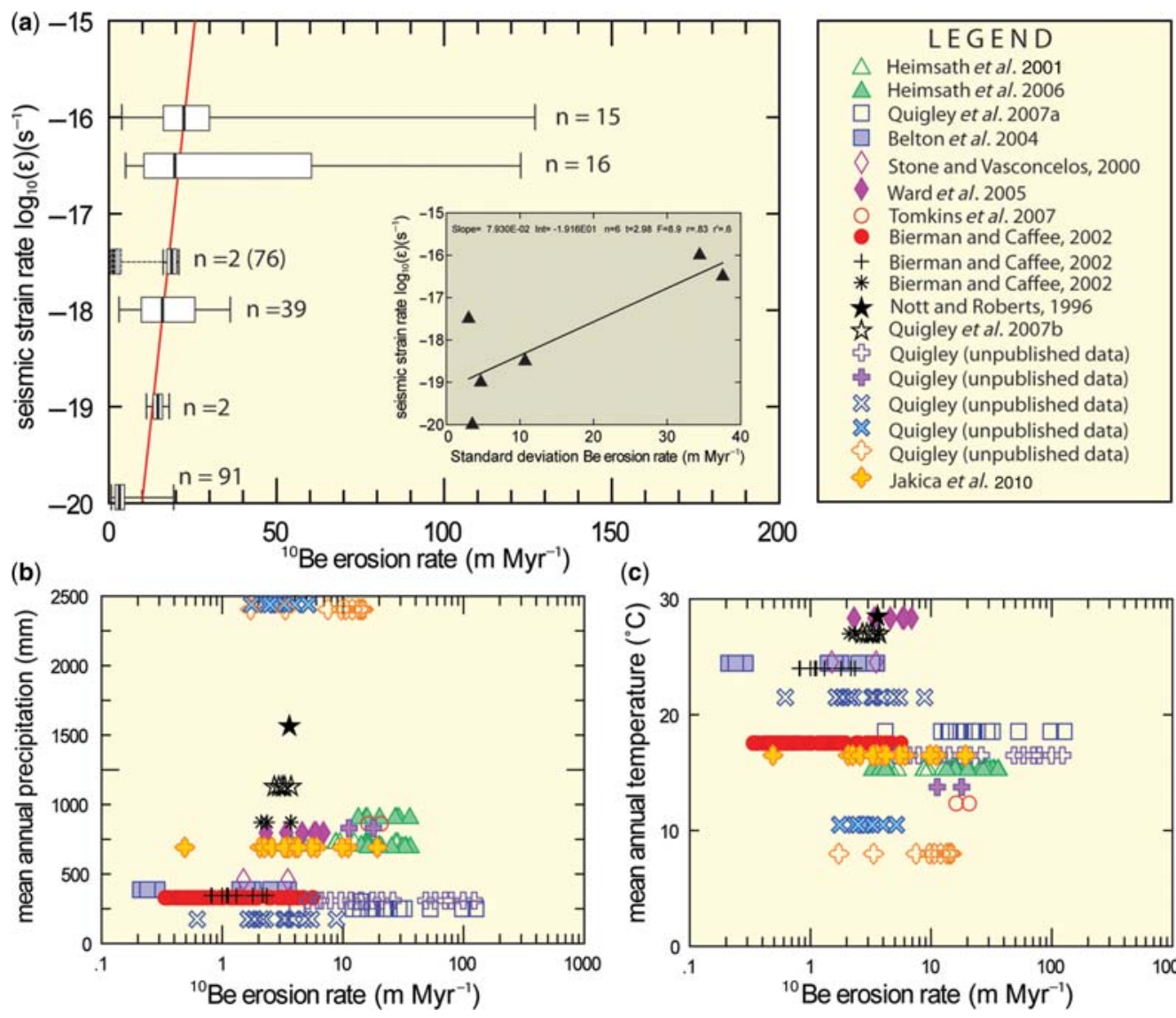

(c)

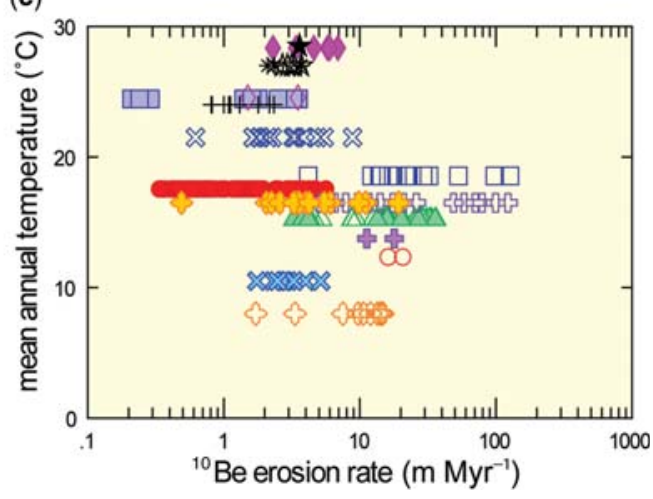

Fig. 10. Cosmogenic ${ }^{10} \mathrm{Be}\left(t_{1 / 2}=1.5 \mathrm{Ma}\right)$ is produced in situ in near-surface materials as a result of high-energy cosmic-ray reactions. Concentrations can be measured using accelerator mass spectrometry and interpreted in terms of surface exposure histories and/or bedrock erosion rates. (a) Whisker-box plot of seismic strain rate (from Braun et al. $2009)$ v. erosion rate (determined from cosmogenic ${ }^{10} \mathrm{Be}$ analyses) for Australian bedrock outcrops across regional tectonic gradients. Outer ticks represent sample minimum and maximum, box boundaries define lower and upper quartiles, and middle line indicates the median erosion rate. $n$, number of samples per suite. For seismic strain rate of $\log _{10}-17.5$, two datasets are shown; inselberg samples (which are relatively unjointed) are discounted from the second, higher erosion rate grouping to compare similar rock masses with consistent joint spacing throughout this analysis. The best-fit line through the data shows an increase in bedrock erosion rate with increasing seismic strain rate, suggesting a first-order tectonic control on bedrock erosion. Qualitatively, increased erosion rates also appear to correlate with increased neotectonic activity (Fig. 8). The inset shows an increase in standard deviation of bedrock erosion for data populations of increasing seismic strain rate. We interpret this to reflect increased erosion rates and erosion rate variability in bedrock landscapes subjected to intermittent large earthquakes and coseismic shaking. (b) Mean annual precipitation v. bedrock erosion rate, showing the absence of any clear correlation between these parameters across large precipitation gradients. (c) Mean annual temperature v. bedrock erosion rate, showing the absence of any clear correlation between these parameters across large mean annual temperature gradients. The results of (b) and (c) suggest that over $10 \mathrm{ka}-1 \mathrm{Ma}$ time scales, climate variability plays a minimal role in determining erosion rate variability for Australian bedrock outcrops relative to tectonic forcing. 
speculated that the large volume of Late Pleistocene sediment accumulated in the Wilkatana fans resulted from reworking of intra-catchment sediment derived from coseismic ground shaking. On the basis of anomalously low cosmogenic ${ }^{10} \mathrm{Be}$ concentrations in bedrock and alluvium derived from fault-affected catchments, Quigley et al. (2007a) suggested that the effects of tectonic perturbations (e.g. anomalously high hillslope sediment volume release as a result of coseismic landslides and anomalously steep longitudinal stream profiles) may reside within Australian landscapes for $c .30 \mathrm{ka}$ or longer. Cosmogenic nuclide concentrations thus appear to provide an informative tool on the degree of neotectonism that has affected Australian bedrock landscapes (Fig. 10). The aseismic Darling escarpment, which has not been affected by late Quaternary tectonism, yields high cosmogenic ${ }^{10} \mathrm{Be}$ concentrations and appears to be in topographic steady state (Jakica et al. 2010) whereas the Flinders Ranges landscapes that have been uplifted in the late Quaternary yield low ${ }^{10} \mathrm{Be}$ concentrations (Quigley et al. 2007a, c). Seismic shaking has produced fractured bedrock slabs or 'A-tents' at several sites in South Australia (Twidale \& Bourne 2000; Twidale \& Campbell 2005), providing an observable connection between earthquake activity and bedrock fracturing. The earthquake recurrence interval and magnitude of coseismic ground shaking associated with seismic events is likely to exert considerable control over the amount of bedrock available for transport during subsequent erosional events (e.g. floods; Quigley et al. 2007c). Kink-bands in c. $120 \mathrm{ka}$ BP interglacial cemented dune limestones near Cape Liptrap provide additional evidence for coseismic rock mass deformation in the Quaternary (Sandiford 2003b; Gardner et al. 2009).

Preliminary investigations of the relationships between bedrock erosion, determined from cosmogenic ${ }^{10} \mathrm{Be}$ concentrations, and extrinsic variables including seismic strain rate, mean annual precipitation, mean annual temperature and temperature range suggest that tectonic activity, as opposed to climate, exerts the dominant control on bedrock erosion rate across the Australian continent (Fig. 10). Intriguingly, a continent-wide inventory of cosmogenic nuclide erosion rate determinations indicates that bedrock erosion rates are low $\left(0.5-5 \mathrm{~m} \mathrm{Ma}^{-1}\right)$ with low variability across large climatic gradients, implying that on time scales of $10-100 \mathrm{ka}$, climate appears to play a minimal role in modulating bedrock erosion rates (Fig. 10; Quigley et al. 2007a; Quigley 2008). Conversely, erosion rates are highly variable (c. 3-130 $\mathrm{m} \mathrm{Ma}^{-1}$ ) in regions of elevated seismic activity (high seismic strain rate) relative to regions of relatively low seismic activity (low seismic strain rate)
(Fig. 10; Quigley et al. 2007a, c; Jakica et al. 2010). We interpret this dataset to indicate that coseismic rock fracturing and transport during infrequent earthquakes is the primary driver of long-term erosion in bedrock landscapes. Although this is perhaps not a surprising conclusion to be drawn from tectonically active regions (Riebe et al. $2001 a, b)$, it is perhaps more remarkable for a mild intraplate setting such as Australia.

\section{Conclusions}

Many of Australia's landscapes have developed in response to active geodynamic processes, including long-wavelength continental tilting, intermediatewavelength folding, and short-wavelength fault displacement of the surface. These processes have extensively modified the coastline of Australia, strongly influenced patterns of marine inundation, and influenced the geometry of many of Australia's streams, hillslopes, basins, and uplands over the last 5-10 Ma. New techniques such as cosmogenic nuclide analysis have allowed bedrock erosion rates, surface uplift rates, and relief production rates to be quantified in selected localities. When combined with structural and stratigraphic studies, these results confirm that the geomorphology of parts of the Australian continent has been changed dramatically in the Late Cenozoic in response to active tectonic processes. Although the modern intraplate tectonic regime is characterized by relatively infrequent large earthquakes compared with plate boundary regions, the correlation between bedrock erosion rates and seismic activity suggests that an active tectonic regime continues to exert a profound influence on landscape evolution in parts of the great southern continent.

We thank P. Bishop, T. Gardner and J. Webb for reviews that improved the quality of this paper. Our views on the Australian landscape have profited greatly through discussions with M. Williams, J. Chappell, S. Hill, J. Bowler, K. Fifield, D. Fink, P. Bierman and many others. Some of the unpublished cosmogenic nuclide data were obtained using ANSTO-University of Melbourne collaborative research grants in 2008 and 2009. D.C. publishes with the permission of the CEO of Geoscience Australia.

\section{References}

ABEL, R. S. 1985. Geology of the Lake George Basin, N.S.W. Bureau of Mineral Resources, Geology and Geophysics Record, 1985/4.

Allen, T. I., Gibson, G. \& Cull, J. P. 2005. Stress-field constraints from recent intraplate seismicity in southeastern Australia. Australian Journal of Earth Sciences, 52, 217-229.

Andrews, A. C. 1910. Geographical unity of Eastern Australia in Late and Post Tertiary time. Proceedings 
of the Royal Society of New South Wales, 54, 251-350.

Barber, P. 1988. The Exmouth Plateau deep water frontier: a case study. In: Purcell, P. G. \& Purcell, R. R. (eds) The North West Shelf, Australia. Proceedings of the Petroleum Exploration Society of Australia Symposium. PESA, Perth, 173-187.

BATt, G. E. \& Braun, J. 1999. The tectonic evolution of the Southern Alps, New Zealand: insights from fully thermally coupled dynamical modeling. Geophysical Journal International, 136, 403-420.

BEARD, J. S. 2003. Palaeodrainage and the geomorphologic evolution of passive margins in Southwestern Australia. Zeitschrift für Geomorphologie, 47, 273-288.

Beavis, F. C. 1960. The Tawonga Fault, northeast Victoria. Proceedings of the Royal Society of Victoria, 72, 95-100.

Beavis, F. C. \& Beavis, J. C. 1976. Structural geology in the Kiewa region of the Metamorphic Complex, North-East Victoria. Proceedings of the Royal Society of Victoria, 88, 66-75.

Belperio, A. P. 1995. Quaternary. In: DreXel, J. F. \& PreIss, W. V. (eds) The Geology of South Australia, Volume 2, The Phanerozoic. Geological Survey of South Australia Bulletin, 54, 219-281.

Belperio, A. P., Harvey, N. \& Bourman, R. P. 2002. Spatial and temporal variability in the Holocene sea-level record of the South Australian coastline. Sedimentary Geology, 150, 153-169.

Belton, D. X., Brown, R. W., Kohn, B. P., Fink, D. \& FARLEY, K. A. 2004. Quantitative resolution of the debate over antiquity of the central Australian landscape: implications for the tectonic and geomorphic stability of cratonic interiors. Earth and Planetary Science Letters, 219, 21-34.

Bierman, P. R. \& Caffee, M. 2002. Cosmogenic exposure and erosion history of Australian bedrock landforms. Geological Society of America Bulletin, 114, 787-803.

BINKs, P. J. 1972. Late Cainozoic uplift of the Ediacara Range, South Australia. Proceedings of the Australian Institute of Minerals and Metallurgy, 243, 47-55.

Bishop, P. 1984. Modern and ancient rates of erosion of central eastern N.S.W. and their implications. In: Loughran, R. J. (compiler) Drainage Basin Erosion and Sedimentation. University of Newcastle and Soil Conservation Service of NSW, Newcastle, 35-42.

BIsHOP, P. 1985. Southeast Australian Late Mesozoic and Cenozoic denudation rates. A test for late Tertiary increases in continental denudation. Geology, 13, 469-482.

Bishop, P., Hunt, P. \& Schmidt, P. W. 1982. Limits to the age of the Lapstone Monocline, N.S.W.; a palaeomagnetic study. Journal of the Geological Society of Australia, 29, 319-326.

Bock, Y., Prawirodirdjo, L. ET AL. 2003. Crustal motion in Indonesia from Global Positioning System measurements. Journal of Geophysical Research, 108, 2367, doi: 10.1029/2001JB000324.

Bourman, R. P. \& Lindsay, J. M. 1989. Timing, extent and character of late Cainozoic faulting on the eastern margin of the Mt Lofty Ranges, South Australia. Transactions of the Royal Society of South Australia, 113, 63-67.
BowLER, J. M. 1978. Quaternary climate and tectonics in the evolution of the Riverine Plain, south eastern Australia. In: Williams, M. A. J. (ed.) Landform Evolution in Australasia. ANU Press, Canberra, 70-112.

Bowler, J. M. \& HARFord, L. B. 1966. Quaternary tectonics and the evolution of the Riverine Plain near Echuca, Victoria. Geological Society of Australia Journal, 13, 339-354.

Braun, J., Gesto, F., Burbidge, D., Cummins, P., SandiFORD, M., GLEADOW, A. \& KoHN, B. 2009. Constraints on the current rate of deformation and surface uplift of the Australian continent from a new seismic database. Australian Journal of Earth Sciences, 56, 99-110.

Brown, C. M. \& Stephenson, A. E. 1991. Geology of the Murray Basin, Southeastern Australia. Bureau of Mineral Resources, Geology \& Geophysics Australia Bulletin, 235.

Browne, W. R. 1967. Geomorphology of the Kosciusko block and its north and south extensions. Proceedings of the Linnean Society of New South Wales, 92, $117-144$.

Callen, R. A. \& Cowley, W. M. 1998. Billla Kalina Basin. In: Drexel, J. F. \& Preiss, W. V. (eds) The Geology of South Australia, Volume 2, the Phanerozoic. South Australia Geological Survey Bulletin, 54, $195-198$.

Cèlérier, J., SANDiford, M., Hansen, D. L. \& Quigley, M. 2005. Modes of active intraplate deformation, Flinders Ranges, Australia. Tectonics, 24, doi: 10.029/2004\&C001679.

Chappell, J. 2006. Australian landscape processes measured with cosmogenic nuclides. In: Pillans, B. (ed.) Regolith Geochronology and Landscape Evolution. CRC LEME, Perth, 19-26.

ClaRK, D. 2006. Neotectonics-based intraplate seismicity models and seismic hazard. Paper presented at Australian Earthquake Engineering Society Meeting, Albury, NSW. World Wide Web Address: http://www.aees. org.au/Proceedings/2006_Papers/069_Clark.pdf.

Clark, D. 2009. Potential geologic sources of seismic hazard in the Sydney Basin: proceedings volume of a one day workshop, April 2005. Geoscience Australia Record, 2009/011.

Clark, D. 2010. Identification of Quaternary scarps in southwest and central west Western Australia using DEM-based hill shading: application to seismic hazard assessment and neotectonics. In: Special Publication of the International Journal of Remote Sensing (in press).

Clark, D. \& McCue, K. 2003. Australian palaeoseismology: towards a better basis for seismic hazard estimation. Annals of Geophysics, 46, 1087-1105.

Clark, D., Van Dissen, R., Cupper, M., Collins, C. \& Prendergast, A. 2007. Temporal clustering of surface ruptures on stable continental region faults: a case study from the Cadell Fault scarp, south eastern Australia. Paper presented at Australian Earthquake Engineering Society Conference, Wollongong. World Wide Web Address: http://www.aees.org.au/ Proceedings/2007_Papers/17_Clark\%2c_Dan.pdf.

Clark, D., Dentith, M., Wyrwoll, K. H., Yanchou, L., Dent, V. \& Featherstone, C. 2008. The Hyden fault scarp, Western Australia: paleoseismic evidence for repeated Quaternary displacement in an intracratonic 
setting. Australian Journal of Earth Sciences, 55, 379-395.

Clark, D. J. \& Leonard, M. 2003. Principal stress orientations from multiple focal plane solutions: new insight into the Australian intraplate stress field. In: HiLlis, R. R. \& Muller, D. (eds) Evolution and Dynamics of the Australian Plate. Geological Society of Australia and Geological Society of America Joint Special Publication, 22, 91-105.

Clark, D. J., Cupper, M., Sandiford, M. \& Kiernan, K. 2010. Style and timing of late Quaternary faulting on the Lake Edgar Fault, southwest Tasmania, Australia: implications for hazard assessment in intracratonic areas. In: Paleoseismology. Geological Society of America, Special Papers (in press).

Cloetingh, S. \& Wortel, R. 1986. Stress in the Indo-Australian plate. Tectonophysics, 132, 49-67.

CoAts, R. P. 1973. Copley map sheet. South Australia. Geological Survey of South Australia. Geological Atlas 1:250 000 Series, Sheet SH54-09.

Coblentz, D. D., SAndiford, M., Richardson, R. M., Zhou, S. \& Hillis, R. 1995. The origins of the intraplate stress field in continental Australia. Earth and Planetary Science Letters, 133, 299-309.

Coblentz, D. D., Zhou, S., Hillis, R. R., Richardson, R. M. \& SANDIFORD, M. 1998. Topography boundary forces and the Indo-Australian intraplate stress field. Journal of Geophysical Research, 103, 919-938.

Crawford, A. R. 1965. The geology of Yorke Peninsula. South Australia. Geological Survey of South Australia Bulletin, 39.

Crone, A. J. \& Machette, M. N. 1997. The temporal variability of surface-faulting earthquakes in stable continental regions; a challenge to seismic-hazard assessments. Geological Society of America, Abstracts with Programs, 29, 71.

Crone, A. J., Machette, M. \& Bowman, J. R. 1997. Episodic nature of earthquake activity in stable continental regions revealed by palaeoseismicity studies of Australian and North American quaternary faults. Australian Journal of Earth Sciences, 44, 203-214.

Crone, A. J., de Martini, P. M., Machette, M. N., Okumura, K. \& Prescott, J. R. 2003. Paleoseismicity of two historically quiescent faults in Australia: implications for fault behavior in stable continental regions. Bulletin of the Seismological Society of America, 93, 1913-1934.

DE Broeckert, P. \& SANdiford, M. 2005. Buried insetvalleys in the eastern Yilgarn Craton, Western Australia: geomorphology, age, and allogenic control. Journal of Geology, 113, 471-493.

DeMets, C., Gordon, R. G., Argus, D. F. \& Stein, S. 1990. Current plate motions. Geophysical Journal International, 101, 425-478.

DeMets, C., Gordon, R., Argus, D. \& Stein, S. 1994. Effect of recent revisions to the geomagnetic reversal time scale on estimates of current plate motions. Geophysical Research Letters, 21, 2191-2194.

Demidjuk, Z., Turner, S., SAndiford, M., George, R., Foden, J. \& Etheridge, M. 2007. U-series isotope and geodynamic constraints on mantle melting processes beneath the Newer Volcanic Province in South Australia. Earth and Planetary Science Letters, 261, 517-533.
Denham, D., Alexander, L. G. \& Worotnicki, G. 1979. Stresses in the Australian crust; evidence from earthquake and in situ stress measurements. BMR Journal of Australian Geology \& Geophysics, 4, 289-295.

Dentith, M. C. \& Featherstone, W. E. 2003. Controls on intra-plate seismicity in southwestern Australia. Tectonophysics, 376, 167-184.

Dentith, M. C., Clark, D. \& Featherstone, W. E. 2009. Aeromagnetic mapping of Precambrian geological structures that controlled the 1968 Meckering earthquake: implications for intraplate seismicity in Western Australia. Tectonophysics, 475, 544-553.

Dickinson, J. A., Wallace, M. W., Holdgate, G. R., Daniels, J., Gallagher, S. J. \& Thomas, L. 2001. Neogene tectonics in SE Australia: implications for petroleum systems. APPEA Journal, 41, 37-52.

Dickinson, J. A., Wallace, M. W., Holdgate, G. R., Gallagher, S. J. \& Thomas, L. 2002. Origin and timing of the Miocene-Pliocene unconformity in southeast Australia. Journal of Sedimentary Research, 72, 288-303.

Dunham, M. H. R. 1992. The geomorphological nature and age of the linear escarpments of northeast Eyre Peninsula. BSc Hons thesis, University of Adelaide.

Dyksterhuis, S. \& Müller, R. D. 2008. Cause and evolution of intraplate orogeny in Australia. Geology, 36, 495-498.

Estrada, B. 2009. Neotectonic and Palaeoseismological Studies in the Southwest of Western Australia. PhD thesis, University of Western Australia, Perth.

FENNER, C. 1930. The major structural and physiographic features of South Australia. Transactions of the Royal Society of South Australia, 54, 1-36.

Fenner, C. 1931. South Australia. A Geographical Study. Whitcombe and Tombs, Melbourne.

Gardner, T., WebB, J. ET AL. 2009. Episodic intraplate deformation of stable continental margins: evidence from Late Neogene and Quaternary marine terraces, Cape Liptrap, Southeastern Australia. Quaternary Science Reviews, 28, 39-53.

Gordon, F. R. \& LewIS, J. D. 1980. The Meckering and Calingiri earthquakes October 1968 and March 1970. Western Australia Geological Survey Bulletin, 126, 229.

Green, M. 2007. The Structure and Kinematics of the Concordia Fault: Constraining the Age of the Indo-Australian Plate Stress Field. BSc Hons thesis, University of Melbourne.

Gurnis, M. 1992. Dynamic topography. In: NierenberG, W. A. (ed.) Encyclopedia of Earth System Science, Vol. 2. Academic Press, San Diego, CA, 105-109.

Gurnis, M., Mueller, R. D. \& Moresi, L. 1998. Dynamics of Cretaceous vertical motion of Australia and the Australian-Antarctic discordance. Science, 279, 1499-1504.

Harris, W. K., Lindsay, J. M. \& Twidale, C. R. 1980. Possible western outlet for an ancient Murray River in South Australia. 2. A discussion. Search, 11, $226-227$.

Hearty, D. J., Ellis, G. K. \& Webster, K. A. 2002. Geological history of the western Barrow Sub-basin: implications for hydrocarbon entrapment at Woollybutt and surrounding oil and gas fields. In: KeEP, M. \& Moss, 
S. J. (eds) The Sedimentary Basins of Western Australia 3. Proceedings of the Petroleum Exploration Society of Australia Symposium. PESA, Perth, 577-598.

Heimsath, A. M., Chappell, J., Dietrich, W. E., NishiIZUMI, K. \& FInKel, R. C. 2001. Late Quaternary erosion in southeastern Australia: a field example using cosmogenic nuclides. Quaternary International, 83-85, 169-185.

Heimsath, A. M., Chappell, J., Finkel, R. C., Fifield, K. \& Alimanovic, A. 2006. Escarpment erosion and landscape evolution in southeastern Australia. In Willet, S. D., Hovius, N., Brandon, M. T. \& Fisher, D. M. (eds) Tectonics, Climate, and Landscape Evolution. Geological Society of America, Special Publication, 398, 173-190.

Hillis, R. \& REYNOLDS, S. 2003. In situ stress field of Australia. In: Hillis, R. R. \& Muller, D. (eds) Evolution and Dynamics of the Australian Plate. Geological Society of Australia, Special Publication, 22, 101-113.

Hillis, R. R. \& ReYnOLds, S. D. 2000. The Australian stress map. Journal of the Geological Society, London, 157, 915-921.

Hillis, R. R., SANDiford, M., Reynolds, S. D. \& Quigley, M. C. 2008. Present-day stresses, seismicity and Neogene-to-Recent tectonics of Australia's 'passive' margins: intraplate deformation controlled by plate boundary forces. In: JOHNSON, H., DoRÉ, A. G., Gatliff, R. W., Holdsworth, R., Lundin, E. R. \& Ritchie, J. D. (eds) The Nature and Origin of Compression in Passive Margins. Geological Society, London, Special Publications, 306, 71-90.

HiLLs, E. S. 1961. Morphotectonics and geomorphological sciences with special reference to Australia. Quarterly Journal of the Geological Society of London, 117, 77-89.

Hills, E. S. 1975. Physiography of Victoria; An Introduction to Geomorphology. Whitcombe \& Tombs, Melbourne.

HockING, R. M. 1988. Regional geology of the northern Carnarvon Basin. In: Purcell, P. G. \& Purcell, R. R. (eds) North West Shelf Symposium, Aug. 10-12, 1988. PESA, Perth, WA, 97-114.

Holdgate, G. R., Wallace, M. W., Gallagher, S. J., Smith, A. J., Keene, J. B., Moore, D. \& Shafik, S. 2003. Plio-Pleistocene tectonics and eustacy in the Gippsland Basin, southeast Australia: evidence from magnetic imagery and marine geological data. Australian Journal of Earth Sciences, 50, 403-426.

Holdgate, G. R., Wallace, M. W., Gallagher, S. J., Wagstaff, B. E. \& Moore, D. 2008. No mountains to snow on: major post-Eocene uplift of the East Victoria Highlands; evidence from Cenozoic deposits. Australian Journal of Earth Sciences, 55, 211-234.

Hutton, J. T., Prescott, J. R., Bowman, J. R., Dunham, M. N. E., Crone, A. J., Machette, M. N. \& Twidale, C. R. 1994. Thermoluminescence dating of Australian palaeoearthquakes. Quaternary Geochronology, 13, $143-147$.

Jakica, S., Quigley, M., Sandiford, M., Clark, D., Fifield, K. \& Alimanovic, A. 2010. Geomorphic evolution of the Darling Scarp, Western Australia: constraints from cosmogenic ${ }^{10} \mathrm{Be}$. Earth Surface Processes and Landforms. doi: 10.1002/esp.2058.
JoHns, R. K. 1968. Investigation of Lake Torrens, report of investigations-South Australia. Geological Survey of South Australia Report of Investigation, 31, 1-62.

Johnson, D. 2004. The Geology of Australia. Cambridge University Press, Cambridge.

Johnston, A. C. 1996. Moment magnitude assessment of stable continental earthquakes, Part 2: historical seismicity. Geophysical Journal International, 125, 639-678.

Johnston, A. C., Coppersmith, K. J., Kanter, L. R. \& CoRnell, C. A. 1994. The earthquakes of stable continental regions. Electric Power Research Institute Report, TR102261V1.

Joyce, E. B. 1975. Quaternary volcanism and tectonics in southeastern Australia. Bulletin of the Royal Society of New Zealand, 13, 169-176.

Kaban, M., Schwintzer, P. \& Reigber, C. 2005. Dynamic topography as reflected in the global gravity field. In: ReIgber, C., LüHR, H., Schwintzer, P. \& WICKERT, J. (eds) Earth Observation with CHAMP: Results from Three Years in Orbit. Springer, Berlin.

Keep, M., Bishop, A. \& Longley, I. 2000. Neogene wrench reactivation of the Barcoo sub-basin, northwest Australia: implications for Neogene tectonics of the northern Australia margin. Petroleum Geoscience, 6, $211-220$.

Keep, M., Clough, M. \& Langhi, L. 2002. Neogene tectonic and structural evolution of the Timor Sea region, NW Australia. In: Keep, M. \& Moss, S. (eds) The Sedimentary Basins of Western Australia III, Proceedings West Australian Basins Symposium. PESA, Perth, 341-353.

LEONARD, M. 2008. One hundred years of earthquake recording in Australia. Bulletin of the Seismological Society of America, 98, 1458-1470.

Lemon, N. M. \& McGowran, B. 1989. Structural Development of the Willunga Embayment, St. Vincent Basin, South Australia. National Centre for Petroleum Geology and Geophysics, Adelaide (unpublished).

Lewis, J. D., Daetwyler, N. A., Bunting, J. A. \& MonCRIEFF, J. S. 1981. The Cadoux Earthquake. Western Australia Geological Survey Report, 1981/11.

Lithgow-Bertelloni, C. \& Gurnis, M. 1997. Cenozoic subsidence and uplift of continents from time-varying dynamic topography. Geology, 25, 735-738.

Machette, M. N., Crone, A. J. \& Bowman, J. R. 1993. Geologic investigations of the 1986 Marryat Creek, Australia, earthquake-implications for paleoseismicity in stable continental regions. US Geological Survey Bulletin, 2032-B, 29.

Martinod, J. \& Molnar, P. 1995. Lithospheric folding in the Indian Ocean and the rheology of the oceanic plate. Bulletin de la Société Géologique de France, 166, 813-821.

Massell, C. G., Coffin, M. F. et AL. 2000. Neotectonics of the Macquarie Ridge Complex, Australia-Pacific plate boundary. Journal of Geophysical Research, 105, $13457-13480$.

Miles, K. R. 1952. Tertiary faulting in northeastern Eyre Peninsula. Transactions of the Royal Society of South Australia, 75, 89-96.

Mitrovica, J. X., Beaumont, C. \& Jarvis, G. T. 1989. Tilting of continental interiors by the dynamical effects of subduction. Tectonics, 8, 1078-1094. 
Molnar, P., England, P. \& Martinod, J. 1993 Mantle dynamics, the uplift of the Tibetan Plateau, and the Indian monsoon. Reviews of Geophysics, 31, 357-396.

Murray-Wallace, C. V. \& Belperio, A. P. 1991. The last interglacial shoreline in Australia; a review. Quaternary Science Reviews, 10, 441-461.

Nelson, E., Hillis, R. et AL. 2006. Present-day stateof-stress of southeast Australia. APPEA Journal, 46, $283-305$.

Neumann, N., SAndiford, M. \& Foden, J. 2000. Regional geochemistry and continental heat flow: Implications for the origin of the South Australian heat flow anomaly. Earth and Planetary Science Letters, 183, 107-120.

Nott, J. \& Roberts, R. G. 1996. Time and process rates over the past 100 m.y.: a case for dramatically increased landscape denudation rates during the late Quaternary in northern Australia. Geology, 24, 883-887.

PACKHAM, G. 1996. Cenozoic SE Asia; reconstructing its aggregation and reorganisation. In: HALL, R. \& BLUNDELl, D. J. (eds) Tectonic Evolution of Southeast Asia. Geological Society, London, Special Publications, 106, 123-152.

Paine, M. D., Bennetts, D. A., Webb, J. A. \& Morland, V. J. 2004. Nature and extent of Pliocene strandlines in southwestern Victoria and their application to Late Neogene tectonics. Australian Journal of Earth Sciences, 51, 407-422.

Pazzaglia, F. \& Gardner, T. 1994. Late Cenozoic flexural deformation of the middle U.S. Atlantic passive margin. Journal of Geophysical Research, 99, $12143-12157$.

Pillans, B. 2003. Dating ferruginous regolith to determine seismic hazard at Lucas Heights, Sydney. In: RoACH, I. C. (ed.) Advances in Regolith: Proceedings of the CRC LEME Regional Regolith Symposia, 2003. CRC LEME, Bentley, Western Australia, 324-327.

Pysklywec, R. N. \& Mitrovica, J. X. 1999. The role of subduction-induced subsidence in the evolution of the Karoo Basin. Journal of Geology, 107, 155-164.

Quigley, M. 2008. Active tectonics, climate change, and surface processes: insights from continent-wide paleoseismic and cosmogenic nuclide datasets. Geological Society of New Zealand Annual Conference Geosciences '08, Wellington, NZ, 25 November 2008.

Quigley, M. C., Cupper, M. L. \& SANDiford, M. 2006. Quaternary faults of southern Australia: palaeoseismicity, slip rates and origin. Australian Journal of Earth Sciences, 53, 285-301.

Quigley, M., Sandiford, M., Alimanovic, A. \& FIFIELD, L. K. 2007a. Landscape responses to intraplate tectonism: quantitative constraints from ${ }^{10} \mathrm{Be}$ abundances. Earth and Planetary Science Letters, 261, 120-133.

Quigley, M., SAndiford, M., Fifield, K. \& AlimanoVIC, A. 2007b. Bedrock erosion and relief production in the northern Flinders Ranges, Australia. Earth Surface Processes and Landforms, 32, 929-944.

Quigley, M. C., SANDiford, M. \& Cupper, M. L. 2007 c. Distinguishing tectonic from climatic controls on range-front sedimentation. Basin Research, doi: 10.1111/j.1365-2117.2007.00336.x.
RaIbeR, M. \& WebB, J. 2008. Tectonic control of Tertiary deposition in the Streatham Deep-Lead System in western Victoria. Australian Journal of Earth Sciences, 55, 493-508.

Reynolds, S. D., Coblentz, D. \& Hillis, R. R. 2003. Influences of plate-boundary forces on the regional intraplate stress field of continental Australia. In: Hillis, R. R. \& Muller, R. D. (eds) Evolution and Dynamics of the Australian Plate. Geological Society of Australia Special Publication, 22, 59-70.

Riebe, C. S., Kirchner, J. W., Granger, D. E. \& Finkel, R. C. 2001a. Strong tectonic and weak climatic control of long-term chemical weathering rates. Geology, 29, $511-514$.

Riebe, C. S., Kirchner, J., Granger, D. \& Finkel, R. 2001b. Minimal climatic control of erosion rates in the Sierra Nevada, California. Geology, 29, 447-450.

Russell, M. \& GuRnis, M. 1994. The planform of epeirogeny: Vertical motions of Australia during the Cretaceous. Basin Research, 6, 63-76.

Rutherfurd, I. D. \& Kenyon, C. 2005. Geomorphology of the Barmah-Millewa forest. Proceedings of the Royal Society of Victoria, 117, 23-39.

SANDIFORD, M. 2003a. Geomorphic constraints on the late Neogene tectonics of the Otway Ranges. Australian Journal of Earth Sciences, 50, 69-80.

SANDIFORD, M. 2003b. Neotectonics of southeastern Australia: linking the Quaternary faulting record with seismicity and in situ stress. In: Hillis, R. R. \& Muller, D. (eds) Evolution and Dynamics of the Australian Plate. Geological Society of Australia Special Publication, 22, 101-113.

SANDIFORD, M. 2007. The tilting continent: a new constraint on the dynamic topographic field from Australia. Earth and Planetary Science Letters, 261, $152-163$.

SANDIFord, M. \& Egholm, D. L. 2008. Enhanced intraplate seismicity along continental margins: Some causes and consequences. Tectonophysics, 457, $197-208$.

SAndiford, M. \& Quigley, M. C. 2009. Topo-Oz: insights into the various modes of intraplate deformation in the Australian continent. Tectonophysics, doi: 10.1016/j.tecto.2009.01.028.

Sandiford, M., Wallace, M. \& Coblentz, D. 2004. Origin of the in situ stress field in southeastern Australia. Basin Research, 16, 325-338.

SAndiford, M., Quigley, M., De Broekert, P. \& JaKica, S. 2009. Tectonic framework for the Cainozoic cratonic basins of Australia. Australian Journal of Earth Sciences, 56, 5-18.

Sharp, K. R. 2004. Cenozoic volcanism, tectonism and stream derangement in the Snowy Mountains and northern Monaro of New South Wales. Australian Journal of Earth Sciences, 51, 67-83.

Singh, G., Opdyke, N. D. \& Bowler, J. M. 1981. Late Cainozoic stratigraphy, magnetic chronology and vegetational history from Lake George, N.S.W. Journal of the Geological Society of Australia, 28, $435-452$.

Stephenson, A. E. 1986. Lake Bungunnia; a PlioPleistocene megalake in southern Australia. 
Palaeogeography, Palaeoclimatology, Palaeoecology, 57, $137-156$.

Stern, T. A., Quinlan, G. M. \& Holt, W. E. 1992. Basin formation behind an active subduction zone: threedimensional flexural modelling of Wanganui Basin, New Zealand. Basin Research, 4, 197-214.

Stone, J. \& VAsconcelos, P. 2000. Studies of geomorphic rates and processes with cosmogenic isotopes-examples from Australia. Goldschmidt 2000 Journal of Conference Abstracts, 5, 961.

Stone, T. 2006. Late Quaternary Rivers and Lakes of the Cadell Tilt Block Region, Murray Basin, Southeastern Australia. PhD thesis, University of Melbourne.

Tokarev, V., Sandiford, M. \& Gostin, V. 1999. Landscape evolution in the Mount Lofty Ranges: Implications for regolith development. Paper presented at Regolith '98; Australian Regolith and Mineral Exploration; New Approaches to an Old Continent; 3rd Australian Regolith Conference, Kalgoorlie, Western Australia, 2-9 May 1998.

Tomkins, K. M., Humphreys, G. S. ET AL. 2007. Contemporary $\mathrm{v}$. long term denudation along a passive plate margin; the role of extreme events. Earth Surface Processes and Landforms, 32, 1013-1031.

Twidale, C. R. 1994. Gondwanan (Late Jurassic and Cretaceous) palaeosurfaces of the Australian Craton. Palaeogeography, Palaeoclimatology, Palaeoecology, 112, 157-186.

Twidale, C. R. 2000. Early Mesozoic (?Triassic) landscapes in Australia: evidence, argument, and implications. Journal of Geology, 108, 537-552.

Twidale, C. R. \& Bourne, J. A. 2000. Rock bursts and associated neotectonic forms at Minnipa Hill, northwestern Eyre Peninsula, South Australia. Environmental and Engineering Geoscience, 2, 129-140.

Twidale, C. R. \& Bourne, J. A. 2004. Neotectonism in Australia: its expressions and implications. Geomorphologie, 3, 179-194.

Twidale, C. R. \& Campbell, E. M. 2005. Australian Landforms: Understanding a Low, Flat, Arid and Old Landscape. Rosenberg, Kenthurst, NSW.

van de Graaff, W. J. E., Denman, P. D. \& Hocking, R. M. 1976. Emerged Pleistocene marine terraces on Cape Range, Western Australia. Western Australia Geological Survey Annual Report, 1975, 62-70.

Veevers, J. J. 2000. Billion-Year Earth History of Australia and Neighbours in Gondwanaland. GEMOC Press, Sydney.

VITA-FInZI, C. 2004. Buckle-controlled seismogenic faulting in peninsular India. Quaternary Science Reviews, 23, 2405-2412.

WaClawik, V. G., Lang, S. C. \& Krapf, C. B. E. 2008. Fluvial response to tectonic activity in an intra-continental dryland setting: The Neales River, Lake Eyre, Central Australia. Geomorphology, 102, doi: 10.1016/j.geomorph.2007.06.021.

WALCOTT, R. I. 1998. Modes of oblique compression: late Cainozoic tectonics of the South Island of New Zealand. Reviews of Geophysics, 36, 1-26.

Wallace, M. W., Dickinson, J. A., Moore, D. H. \& SanDIFORD, M. 2005. Late Neogene strandlines of southern Victoria: a unique record of eustasy and tectonics in southeast Australia. Australian Journal of Earth Sciences, 52, 279-297.

Ward, I., Nanson, G., Head, L., Fullagar, R., Price, D. \& FINK, D. 2005. Late Quaternary landscape evolution in the Keep River region, northwestern Australia. Quaternary Science Reviews, 24, 1906-1922.

WebB, J. A. \& James, J. M. 2006. Karst evolution of the Nullarbor Plain, Australia. In: HARMON, R. S. \& WICKs, C. M. (eds) Karst Geomorphology, Hydrology and Geochemistry - a Tribute Volume to Derek C. Ford and William B. White. Geological Society of America, Special Papers, 404, 65-78.

Wegmann, K. W., ZurbeK, B. D. et AL. 2007. Position of the Snake River watershed divide as an indicator of geodynamic processes in the greater Yellowstone region, western North America. Geosphere, 3, 272-281.

Wellman, P. 1979. On the Cainozoic uplift of the southeastern Australian highland. Journal of the Geological Society of Australia, 26, 1-9.

Wellman, P. \& McDougall, I. 1974. Potassium-argon ages on the Cainozoic volcanic rocks of New South Wales. Journal of the Geological Society of Australia, 21, 247-272.

Willet, S. \& Brandon, M. 2002. On steady states in mountain belts. Geology, 30, 175-178.

WiLliams, G. E. 1973. Late Quaternary piedmont sedimentation, soil formation and palaeoclimates in arid South Australia. Zeitschrift für Geomorphologie, 17, $102-123$.

Williams, G. E. \& Goode, A. D. 1978. Possible western outlet for an ancient Murray River in South Australia. Search, 9, 443-447.

Williams, I. R. 1979. Recent fault scarps in the Mount Narryer area, Byro 1:250 000 sheet. Western Australia. Geological Survey. Annual Report, 1978, 51-55.

WopfNer, H. 1968. Cretaceous sediments on the Mt Margaret Plateau and evidence for neo-tectonism. Geological Survey of South Australia Quarterly Geological Notes, 28, 7-11.

Young, R. W. \& MacDougall, I. 1993. Long-term landscape evolution: miocene and modern rivers in southern New South Wales. Journal of Geology, 101, $35-49$. 